\title{
Longitudinal river zonation in the tropics: examples of fish and caddisflies from the endorheic Awash River, Ethiopia
}

\author{
Gernot K. Englmaier (D) - Daniel S. Hayes (D) Paul Meulenbroek (D) \\ Yonas Terefe $\cdot$ Aschalew Lakew $\cdot$ Genanaw Tesfaye $\cdot$ Herwig Waidbacher $(\mathbb{D} \cdot$ \\ Hans Malicky • Alemayehu Wubie • Patrick Leitner $($ D $\cdot$ Wolfram Graf $(\mathbb{D}$
}

Received: 28 March 2020/Revised: 14 August 2020/Accepted: 29 August 2020/Published online: 16 September 2020

(C) The Author(s) 2020

\begin{abstract}
Specific concepts of fluvial ecology are well studied in riverine ecosystems of the temperate zone but poorly investigated in the Afrotropical region. Hence, we examined the longitudinal zonation of fish and adult caddisfly (Trichoptera) assemblages in the endorheic Awash River (1,250 km in length), Ethiopia. We expected that species assemblages are structured along environmental gradients, reflecting the pattern of large-scale freshwater ecoregions. We applied multivariate statistical methods to test for
\end{abstract}

Gernot K. Englmaier and Daniel S. Hayes: equally contributing authors.

Handling editor: Marcelo S. Moretti

G. K. Englmaier $(\bowtie)$

Institute of Biology, University of Graz, Universitätsplatz

2, 8010 Graz, Austria

e-mail: gernotenglmaier@gmx.at

D. S. Hayes - P. Meulenbroek · Y. Terefe ·

H. Waidbacher · P. Leitner · W. Graf $(\bowtie)$

Institute of Hydrobiology and Aquatic Ecosystem

Management (IHG), Vienna, University of Natural

Resources and Life Sciences, Gregor-Mendel Straße 33,

1180 Vienna, Austria

e-mail: wolfram.graf@boku.ac.at

\section{S. Hayes}

Centro de Estudos Florestais (CEF), Instituto Superior de Agronomia, University of Lisbon, Tapada da Ajuda, 1349-017 Lisbon, Portugal differences in spatial species assemblage structure and identified characteristic taxa of the observed biocoenoses by indicator species analyses. Fish and caddisfly assemblages were clustered into highland and lowland communities, following the freshwater ecoregions, but separated by an ecotone with highest biodiversity. Moreover, the caddisfly results suggest separating the heterogeneous highlands into a forested and a deforested zone. Surprisingly, the Awash drainage is rather species-poor: only 11 fish (1 endemic, 2 introduced) and 28 caddisfly species ( 8 new records for Ethiopia) were recorded from the mainstem and its major tributaries. Nevertheless, specialized species characterize the highland forests,

\author{
Y. Terefe \\ Department of Biological Sciences, Ambo University, \\ P.O. Box 95, Ambo, Ethiopia
}
A. Lakew - G. Tesfaye - A. Wubie
EIAR-National Fisheries and Aquatic Life Research
Center, P.O. Box 64, Sebeta, Ethiopia
H. Malicky
Sonnengasse 13, 3293 Lunz am See, Austria 
whereas the lowlands primarily host geographically widely distributed species. This study showed that a combined approach of fish and caddisflies is a suitable method for assessing regional characteristics of fluvial ecosystems in the tropics.

Keywords Africa - Biodiversity - Biogeography · Species assemblages - Freshwater ecoregions .

Indicator species

\section{Introduction}

In the early to mid-twentieth century, limnologists intensively described the longitudinal distribution of aquatic communities along rivers (e.g. Thienemann, 1925; Huet, 1949; Harrison \& Elsworth, 1958; Illies, 1961a, b; Illies \& Botosaneanu, 1963). These studies enhanced the understanding of fluvial ecosystems, and the river continuum concept even became a frequently tested hypothesis in applied fluvial ecology (Vannote et al., 1980). Since then, knowledge on riverine distribution patterns has been used, for example, to establish bioindication systems (e.g. Schmidt-Kloiber \& Hering, 2015) and river assessment criteria (e.g. Aarts \& Nienhuis, 2003; Welcome et al., 2005).

Nevertheless, taxonomy and taxa differentiation of many biota, as well as their habitat preferences, functional traits, and distribution patterns, are often still poorly understood (Balian et al., 2008). This is especially the case in tropical rivers (e.g. Gibon \& Statzner, 1985; Malicky \& Chantaramongkol, 1993; Winemiller et al., 2008; Laudee \& Prommi, 2011; Skelton \& Swartz, 2011; Ochieng et al., 2019). Despite recent advances (Malicky \& Chantaramongkol, 1993; Araújo et al., 2009), most conceptual studies on river zonation were conducted in temperate regions of Europe and North America (Hawkes, 1975), which may limit the adoption of established concepts into tropical regions (Araújo et al., 2009). Besides, the lack of knowledge of tropical rivers is a limiting factor in assessing the integrity of these ecosystems. Hence, the scarcity of tropical studies impedes the assessment of diversity and distribution patterns, as well as a comparison to concepts and hypotheses of fluvial ecology of temperate rivers (Ward et al., 2002; Thorp et al., 2006).
At the same time, anthropogenic impacts on aquatic ecosystems are rapidly increasing on a global scale (Darwall et al., 2018; Sabater et al., 2018). The effects of deforestation, intensification of agriculture and other land-use changes, hydropower, river engineering, and water pollution threaten aquatic biodiversity (e.g. Clausen \& York, 2008; Fitzgerald et al., 2018; Hayes et al., 2018, 2019; Meulenbroek et al., 2019). These trends can even have visible impacts on largescale ecosystem processes (Darwall et al., 2018). The serial discontinuity concept was developed to address these pressures (Ward \& Stanford, 1983, 1995). It suggests that dams and other anthropogenic stressors can disrupt the underlying natural gradient and cause an upstream or downstream shift of species, as well as divide the river network into discrete zones. However, natural influences such as lakes can also create comparable patterns (Stanford et al., 1988). Hence, it is evident that, in contrast to the assumption of an uninterrupted gradient (Vannote et al., 1980), discontinuities or transition zones constitute a significant component of faunal zonation (Statzner \& Higler, 1986). Moreover, certain functional process zones may repeatedly appear along a river and even form comparable patterns within an ecoregion. Beyond the ecoregional level, however, such patterns may be less predictable (Thorp et al., 2006). Therefore, it must be clarified if and to which extent zonation studies conducted in tropical streams and rivers also reveal such discontinuities reported for other systems (Araújo et al., 2009), as well as if the ecoregion regulates community zonation (Thorp et al., 2006).

Fish (Pisces) and caddisflies (Insecta: Trichoptera) are widely used to describe longitudinal changes of community structures (e.g. Harrison \& Elsworth, 1958; Lévêque et al., 1983; Stanford et al., 1988). These two organism groups provide the advantage of relatively low sampling effort, the coverage of diverse habitat characteristics in the respective river stretches, and a more profound taxonomic knowledge in comparison to other organism groups. Besides, both groups have a high indicative power regarding environmental conditions. They are therefore implemented within the EU Water Framework Directive (2000/60/ EC) as faunistic biological quality elements to assess the ecological status of freshwater systems. Whilst fish mostly respond to mesohabitat characteristics, caddisflies depend more on the availability of microhabitats. Particularly the latter is increasingly used for 
ecological status assessment of African rivers (e.g. Dickens \& Graham, 2002; Masese et al., 2009; Kaaya et al., 2015; Lakew \& Moog, 2015; Alemneh et al., 2019). However, ecological studies in riverine ecosystems of the Afrotropical region often rely on a high level of taxonomic resolution, such as family or genus level (e.g. Kaaya et al., 2015; Lakew \& Moog, 2015; Alemneh et al., 2019), despite the importance of including species-level information to enhance understanding of distribution patterns (Malicky \& Chantaramongkol, 1993). So far, however, species-specific studies throughout the Afrotropical realm mainly focused on taxonomy or a wide biogeographic context (e.g. Roberts, 1975) but rarely covered aquatic communities in entire river systems (Harrison \& Elsworth, 1958; Payne et al., 2010).

In this study, we explored the longitudinal zonation of fish and adult caddisfly species in a long ( $>1,000 \mathrm{~km}$, sensu Grill et al., 2019) tropical river in East Africa, including its major tributaries. We selected the Awash River in the Main Ethiopian Rift as a case study because of several unique characteristics: the river is an endorheic drainage which flows into the Afar Depression, an arid region; it exhibits a distinctive tectonic setting with a stepwise longitudinal and altitudinal gradient; and the drainage is subdivided into two freshwater ecoregions, the Ethiopian Highlands and the Northern Eastern Rift (Abell et al., 2008). Our overall objective was to describe longitudinal zonation patterns of the fish and caddisfly assemblages in the Awash River drainage by providing species-level information as the most reliable basis for assessment. By using a combined approach of fish, adult caddisflies, and environmental variables, we aimed to answer the following questions: How are fish and caddisfly species distributed longitudinally along a tropic endorheic river and its major tributaries? Can distinct species assemblages be distinguished, and, if yes, which environmental parameters are crucial in steering community composition in the dry season? Besides, we wanted to know if both organism groups show the same distribution and grouping pattern. Moreover, to assist in improved river management, we aimed to detect indicator species characteristic of the observed biocoenoses. Based on theoretical concepts, we expected that species assemblages are structured along environmental gradients and reflect the pattern of large-scale freshwater ecoregions. Accordingly, transition zones between discrete biocoenoses with shared species of both adjacent communities should exist.

\section{Materials and methods}

Study area and sampling sites

The Awash River catchment, with an area of $112,696 \mathrm{~km}^{2}$, is home to approximately 14.9 million people, making it one of the most important and industrialized drainage basins in Ethiopia (Tesfaye \& Wolff, 2014; Ministry of Environment, Forest and Climate Change, MEFCC, 2018). The Awash River springs in the Ethiopian Highlands at an altitude of $>3,000 \mathrm{~m}$. It flows for $1,250 \mathrm{~km}$ along the northern part of the Main Ethiopian Rift, where it finally drains into saline Lake Abbe at the Ethiopian-Djibouti border at an altitude of around $250 \mathrm{~m}$ (Tesfaye \& Wolff, 2014; Tadese et al., 2019). Most tributaries originate in the highlands and join the mainstem river from the West (Fig. 1).

In the highlands, the mean annual precipitation amounts to $1,600 \mathrm{~mm}$, and only $160 \mathrm{~mm}$ in the northern part of the catchment (Edossa et al., 2010). Similarly, the mean annual air temperature exhibits a spatial variation from 16.7 to $34.5^{\circ} \mathrm{C}$ (Keraga et al., 2019). The drainage basin consists of two freshwater ecoregions: the Ethiopian Highlands and the Northern Eastern Rift (Abell et al., 2008).

To study the distribution of the fish and caddisfly fauna, we sampled the Awash River from the source region in the Chilimo Forest to the lakes in the Afar Depression, as well as seven of its tributaries, draining the southern slopes of the Ethiopian Highlands into the Main Ethiopian Rift (Fig. 1; Table 1). We selected a total of 24 sampling sites (16 in the Awash River and 8 in the tributaries) based on habitat criteria (natural riparian vegetation, diverse meso- and microhabitat structures), tectonic setting (geomorphological characteristics), minimal direct anthropogenic impact, and accessibility (see Englmaier, 2018). The accessibility of river stretches was restricted by the permission of local authorities, dense riparian vegetation, physiography, water depth, or the presence of abundant crocodiles.

Sites S1-5 (Awash) and T8 (tributary) are located in the Ethiopian Highlands freshwater ecoregion (Abell et al., 2008). These river stretches are usually 


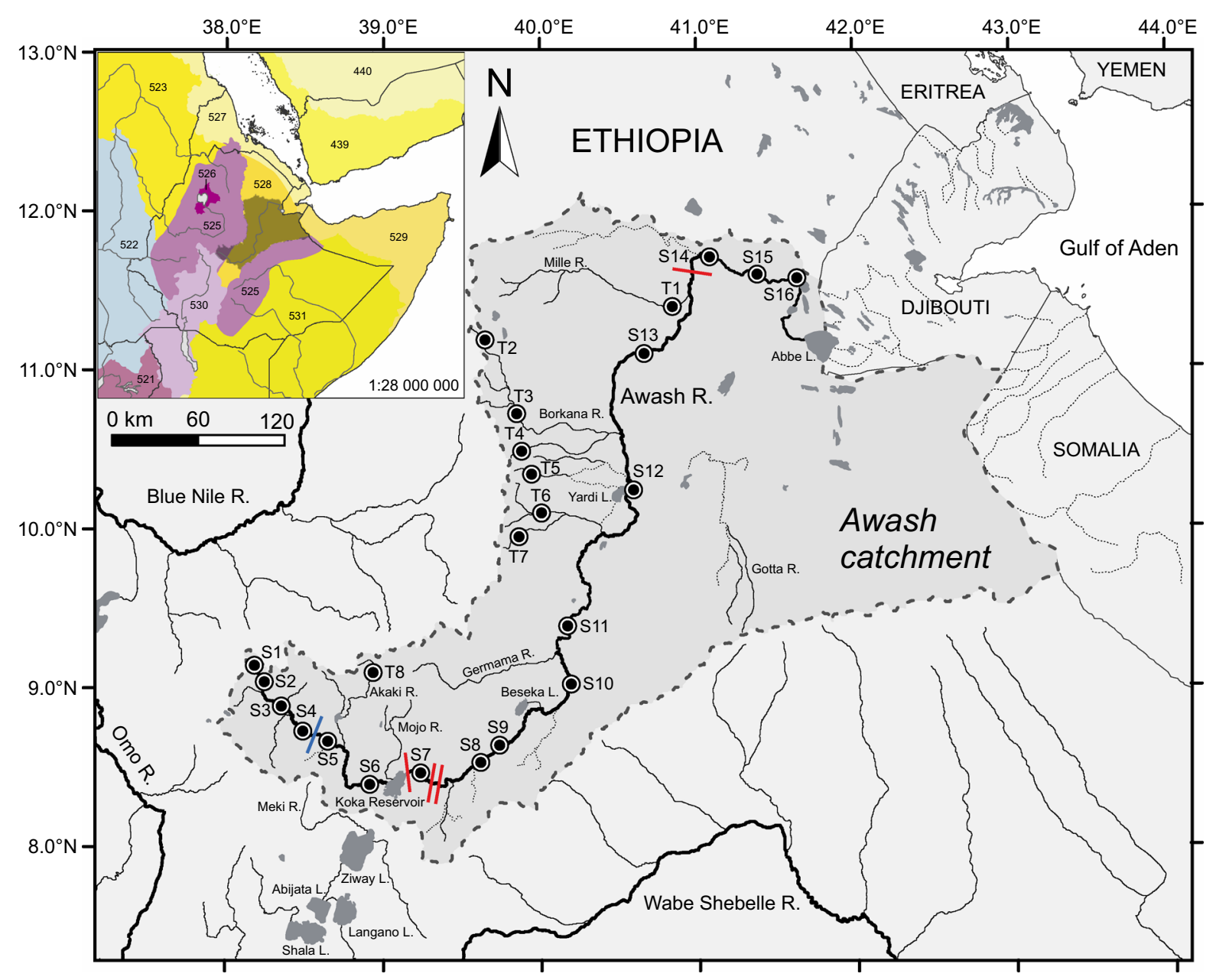

Fig. 1 Map of the study area, location of sampling sites (S1-16, T1-8), dams (red lines), and the cascades at Awash Kunture (blue line). Numbers in the overview map of the Horn of Africa refer to the following freshwater ecoregions (Abell et al., 2008): 439 southwestern Arabian Coast, 440 Arabian Interior, 521

characterized by steep gradients, coarse stony substrate (macrolithal to microlithal, see Table 1), and a confined river course (Englmaier, 2018). With the exception of the protected Chilimo Forest (S1, National Forest Priority Area), the region is subject to extensive anthropogenic impacts with intensive agricultural use and overgrazing by livestock, resulting in the loss of natural vegetation (Tafere et al., 2013; Kebede et al., 2020).

The remaining sites are situated in the Northern Eastern Rift freshwater ecoregion (Abell et al., 2008). Here, the Awash River flows through alternating steep and low gradient sections with sequences of confined river stretches and extensive wetlands (Englmaier,
Lake Victoria Basin, 522 Upper Nile, 523 Lower Nile, 525 Ethiopian Highlands, 526 Lake Tana, 527 Western Red Sea Drainages, 528 Northern Eastern Rift, 529 Horn of Africa, 530 Lake Turkana, 531 Shebelle-Juba

2018). The riverbed consists either of bedrock or sand. In contrast, the tributary sites (T1-7) are characterized by a wide river corridor and coarse substrate (Table 1). In the Northern Eastern Rift, the longitudinal gradient of the Awash River is interrupted by three hydroelectric power plants (Koka Reservoir, Awash II-III) and one irrigation dam (Tendaho Reservoir). At Metahara (downstream of S9), the saline Lake Beseka is artificially connected to the Awash River (Fig. 1).

Field work

We sampled sites during low flow conditions in the dry season over a time frame of 3 years (Table 1). At each 


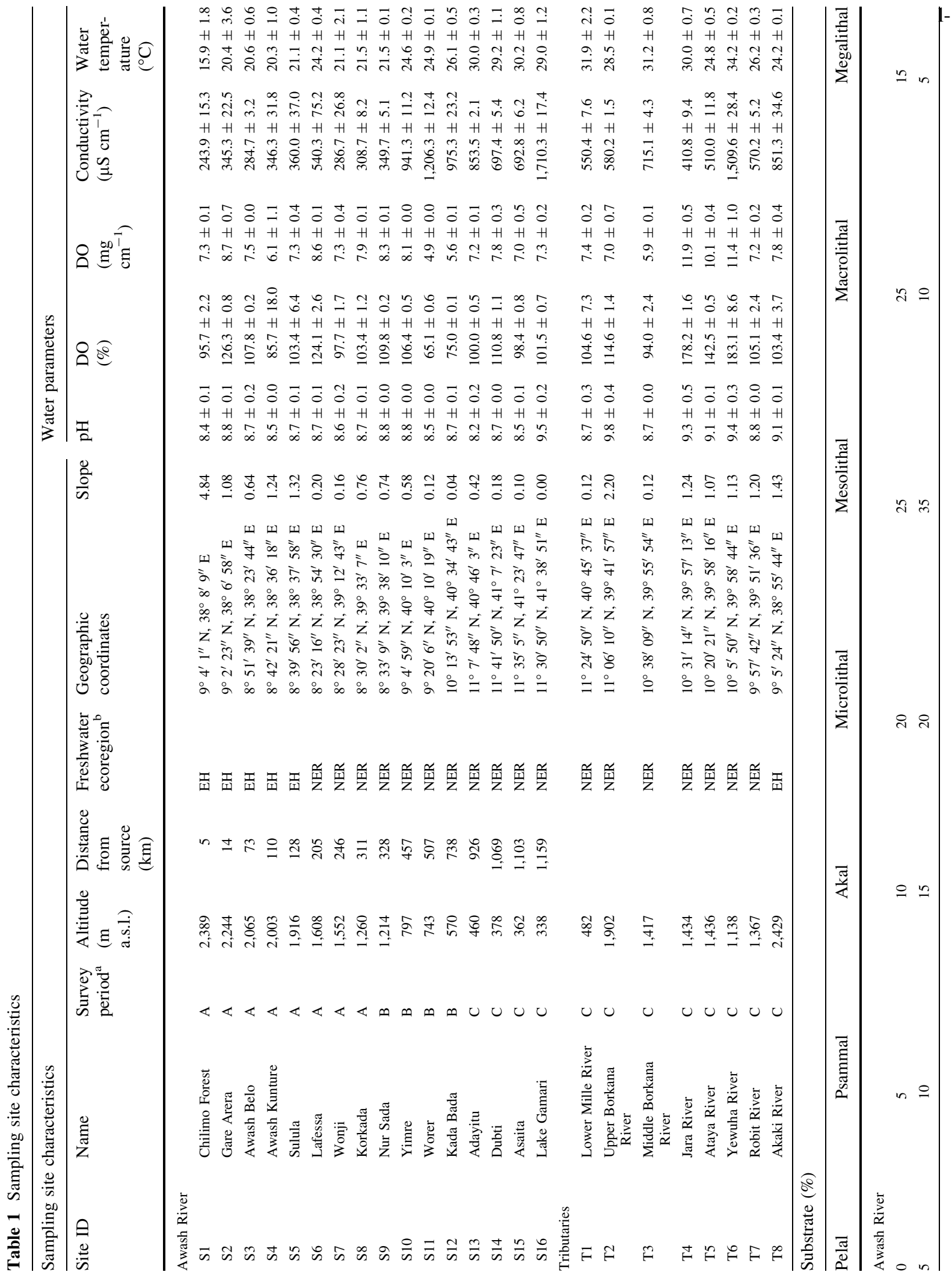




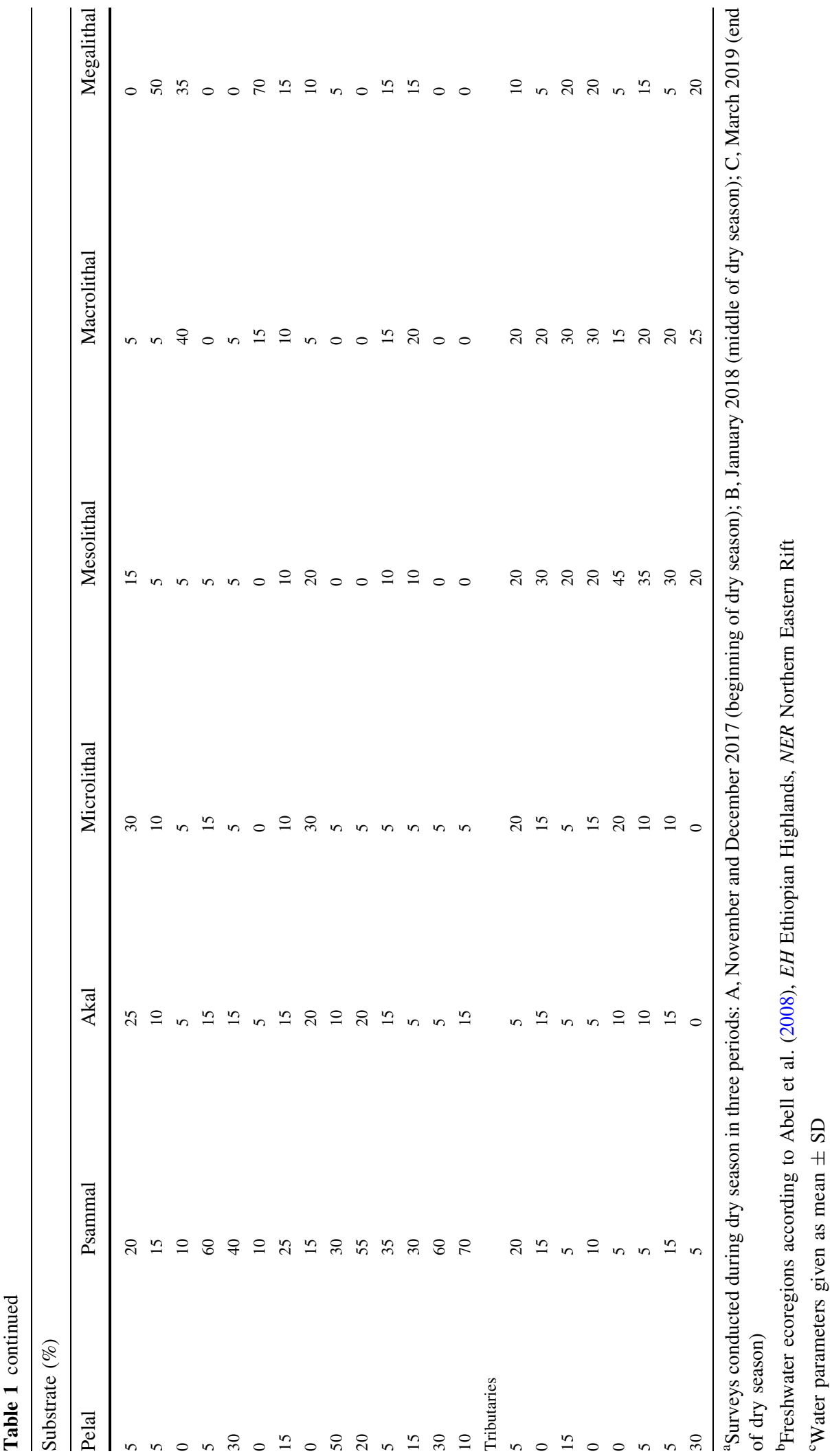


ocation, we investigated a representative stretch with a length between 500 and 1,000 m. In order to link fish and caddisfly presence to abiotic variables, we recorded different water parameters. We measured dissolved oxygen concentration $\left(\%, \mathrm{mg} \mathrm{cm}^{-1}\right)$, conductivity $\left(\mu \mathrm{S} \mathrm{cm}^{-1}\right), \mathrm{pH}$, and water temperature $\left({ }^{\circ} \mathrm{C}\right)$ with a portable $\mathrm{HACH}$-multimeter (HQ40d) at noon in three consecutive measurement series (three replicates each). The probes were placed in swift current $(10 \mathrm{~cm}$ sub-surface) at three different points (each $20 \mathrm{~m}$ apart) without prior disturbance of the upstream reach. In addition, we classified dominating substrate types: pelal, psammal, akal, microlithal, mesolithal, macrolithal, and megalithal (Moog et al., 1999). We recorded geographic coordinates and altitude of each sampling site with a Garmin VISTA e-trex GPSsystem. The distances from the source and slopes of the sampling sites were obtained from Google Earth's digital elevation model (Google Earth Pro v.7.3).

We collected fish from the main river channel, side arms, and the shoreline of lakes. Sampling points included the following mesohabitats: riffles, runs, pools, backwaters, woody debris piles, shoreline vegetation, undercut banks, gravel banks, and inshore areas of lakes. Fishing effort was limited to 100-120 min of active fishing and 2-9 h of passive exposure of gillnets and longlines (where applicable). Wadable stretches were sampled using a back-pack electrofishing unit (Honda GXV 50, direct current $1.5 \mathrm{~kW}, 300 / 580 \mathrm{~V}$ ), seine nets (mesh size $1.5 \mathrm{~mm}$ ), and frame nets (mesh size $1.5 \mathrm{~mm}$ ). In deeper waters, fish were collected with gill nets (mesh sizes $80 \mathrm{~mm}$ and $60 \mathrm{~mm}$ ), cast nets (mesh size $15 \mathrm{~mm}$ ), and longlines. Most fish specimens were identified in the field and released back to the river. A subsample from each locality, including all species and morphotypes, was taken for detailed morphological examination. These specimens were first anesthetized with etheric clove oil diluted in water and later fixed in $6-10 \% \mathrm{pH}$ neutral formalin or $95 \%$ ethanol.

Regarding macroinvertebrates, we chose caddisflies as an indicator group since, aside from their elaborate adult taxonomy, they represent a spectrum of the community that can be attracted and documented by light traps. By targeting adult caddisflies, we aimed at reducing insufficient results due to methodological problems in benthic sampling (e.g. limited accessibility of the entire habitat mosaic of a given site) and due to the low knowledge level on larval taxonomy of
African caddisflies in general (e.g. Scott, 1975; Terefe et al., 2018; Ochieng et al., 2019). Only 105 larval stages of 747 Sub-Saharan species of African caddisflies were known by the early 1980s (Scott, 1983). Since then, only twelve additional studies have produced descriptions of larvae for individual species (e.g. Malicky, 1994; Allaya, 2003; Ogbogu, 2008; Ogbogu \& Okeze, 2008; Terefe et al., 2018).

We collected adult stages of caddisflies from the riparian zone with sweep nets (at dusk for $30 \mathrm{~min}$, mesh size $1 \mathrm{~mm}$ ) and light traps. The traps consisted of a fluorescent tube (15 W Blacklight blue tube) attached upon a rectangular pan $(40 \times 25 \times 7 \mathrm{~cm})$, half-filled with water, and containing detergent to reduce the surface tension. The exposure time of light traps was $60 \mathrm{~min}$, starting from sunset. At each site, we used one light trap. We fixed caddisfly samples in 95\% ethanol for morphological identification.

No caddisfly samples were obtained from S9, S16 (main channel), T4-6, and T8 (tributaries) due to local restrictions. These sites were therefore excluded from the analyses.

Reference material was stored in the collections of the National Fisheries and Aquatic Life Research Centre, Sebeta, Ethiopia (fish and caddisflies), the Natural History Museum Vienna, Austria (fish), as well as the research collections of H. Malicky (Lunz am See, Austria), W. Graf (University of Natural Resources and Applied Life Sciences, Vienna, Austria) and the Senckenberg Research Institute and Museum of Nature (SMF, Frankfurt am Main, Germany) (caddisflies).

\section{Species identification}

All species were identified as morphospecies based on external morphological and meristic traits. The following available literature was used for fish identification: Getahun (2000), Golubtsov et al. (2002), Stiassny \& Getahun (2007), Habteselassie et al. (2010), Habteselassie (2012), and Moritz et al. (2019). Caddisfly identification was based on Tobias $\&$ Tobias (2008) and the reference collections of the authors, with the assistance of François-Marie Gibon. Direct comparison to museum samples (type specimens, comparative material) included specimens in the collections of the Natural History Museum (BMNH, London, England), the Muséum National D'Histoire Naturelle (MNHN, Paris, France), SMF, 
and the research collections of H. Malicky and W. Graf.

For polymorphic fish groups (Garra, Labeobarbus), we followed the group subdivision of Englmaier (2018), which was based on the comparison of $500 \mathrm{bp}$ of the mitochondrial $\mathrm{CO} 1$ gene, with the following clarifications: Garra sp. was identified as Garra makiensis based on the comparison with syntypes at BMNH; G. aff. makiensis was identified as Garra aethiopica based on the comparison with syntypes at MNHN; Labeobarbus cf. intermedius was identified on species level based on the comparison with the holotype at SMF and the genetic analyses of Beshera \& Harris (2014); and L. cf. nedgia (the sympatric "lipped" form of L. intermedius) was provisionally included in L. intermedius.

For information on the author and year of description of the identified species, the reader is referred to Tables 2 and 3.

\section{Data analyses}

We explored patterns in fish and caddisfly assemblage structure and distribution through a multivariate analysis approach. We analyzed the data based on species presence/absence instead of using relative abundances to avoid a systematic bias due to unequal sampling methods. For each organism group and a combined dataset (fish and caddisflies), we performed two-way cluster analyses [CA, using the Jaccard coefficient and flexible beta linkages $(-0.25)]$ and non-metric multidimensional scaling (NMDS, using the Jaccard coefficient) to explore and visualize patterns of similarity in the datasets. Both methods were implemented in PC-ORD v.5.33 (McCune \& Mefford, 2006). Group circumscription in NMDS was based on individual CA, with subdivisions supported by $37.5 \%$ total information used.

Based on the above exploratory tools, we tested the assemblage structure with a permutational multivariate analysis of variance (PERMANOVA; Anderson, 2001), with 999 permutations implemented in the $R$ package vegan (Oksanen et al., 2015) in R v.3.4.3 (R Core Team, 2017).

The identification of indicator species is imperative for the classification and assessment of the ecological integrity of a river ecosystem. As species-specific bioindicators are rare or absent in most of the Afrotropical region, we determined characteristic species for the observed biocoenoses of different river sections by conducting an indicator species analysis (Dufrêne \& Legendre, 1997) with PC-ORD v.5.33 (McCune \& Mefford, 2006). Based on 308 randomizations and 4,999 permutations, only species with an indicator value (IV) of $\geq 40$ and $P<0.05$ (Monte Carlo permutation test) were considered significant. The indicator analysis was based on presence/absence data. Group membership of sampling sites was based on the results of the CA. For all tests, we considered $P<0.05$ as significant.

\section{Results}

Faunal characteristics

We recorded a total of 10,111 fish specimens (11 species, 4 families) and 23,757 adult caddisflies (28 species, 7 families). Of the 11 fish species, 9 are native, and 2 introduced (Cyprinus carpio, Coptodon zillii). Fish species of the family Cyprinidae (three genera, five native species, one introduced species) showed the most dominant occurrence (Table 2). Of these, the genera Garra (three species) and Labeobarbus (two species) were widely distributed throughout the entire drainage system. At species level, L. intermedius was most widespread, with a continuous distribution from S5 to S16 (1,916-338 m) but absent from sampling sites above the cascades at Awash Kunture (upstream of S5). At a few sites (S5, S9-10, and T4), predominantly over coarse substrate, we found the sympatric "lipped" form of L. intermedius. Garra dembeensis was the only species present in both, the source region in the Chilimo Forest (S1, 2,389 $\mathrm{m}$ ) and the Lower Awash (S14, $378 \mathrm{~m})$ but showed a highly fragmented distribution restricted to riffles over a stony substrate. Garra aethiopica and Enteromius yardiensis showed the most restricted distributions. Whilst the former inhabited river stretches $>1,138 \mathrm{~m}$, the latter was found only in lower reaches of the main river channel and aquatic floodplain habitats (S12-16, 570-338 m).

Collections of caddisflies (Table 3) mainly comprised the families Leptoceridae (7 genera, 11 species), Hydropsychidae (3 genera, 8 species), Ecnomidae (1 genus, 3 species), and Hydroptilidae (2 genera, 3 species). A single species was found in each of the remaining families (Dipseudopsidae, Lepidostomatidae, and Polycentropodidae). In total, 


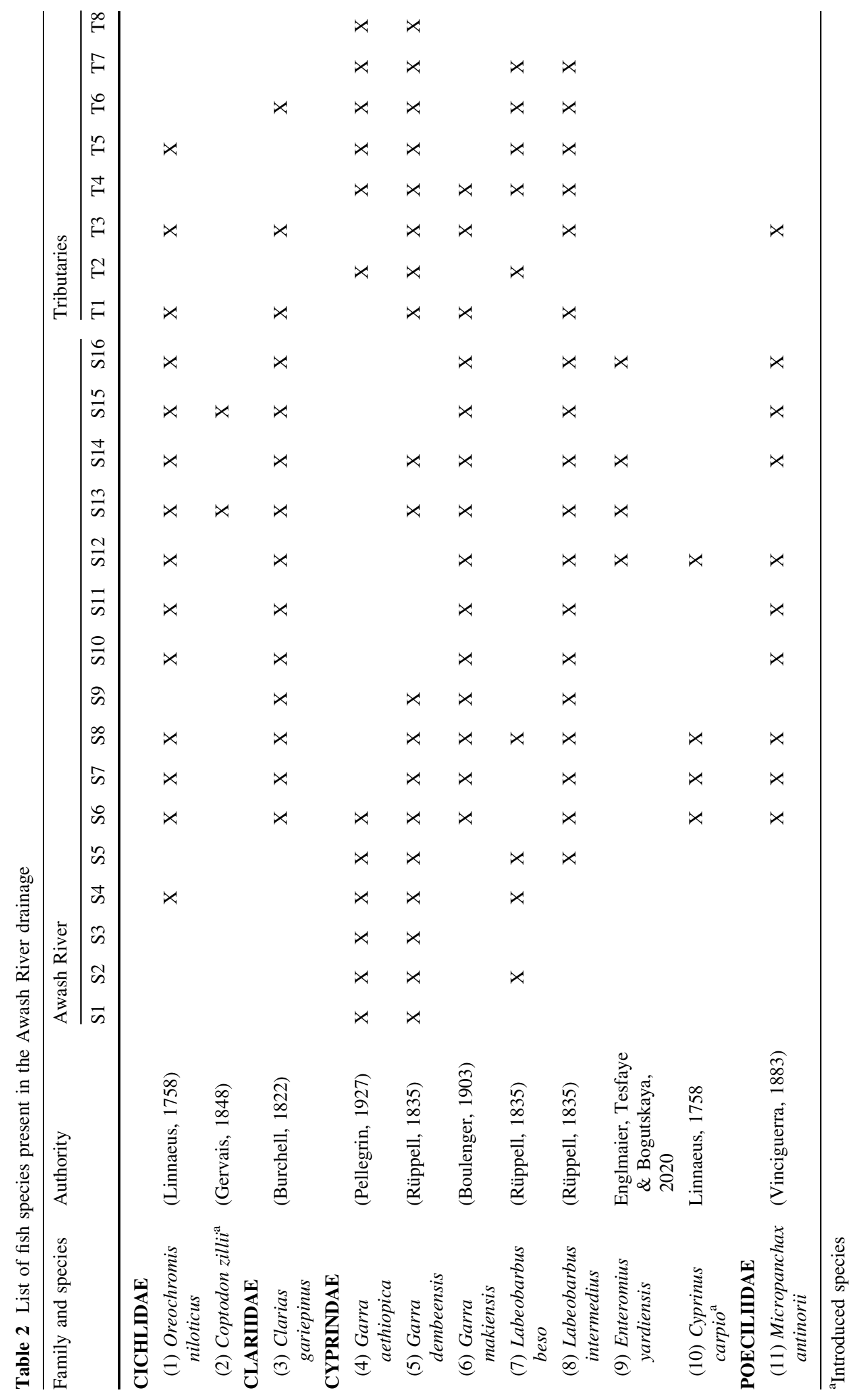




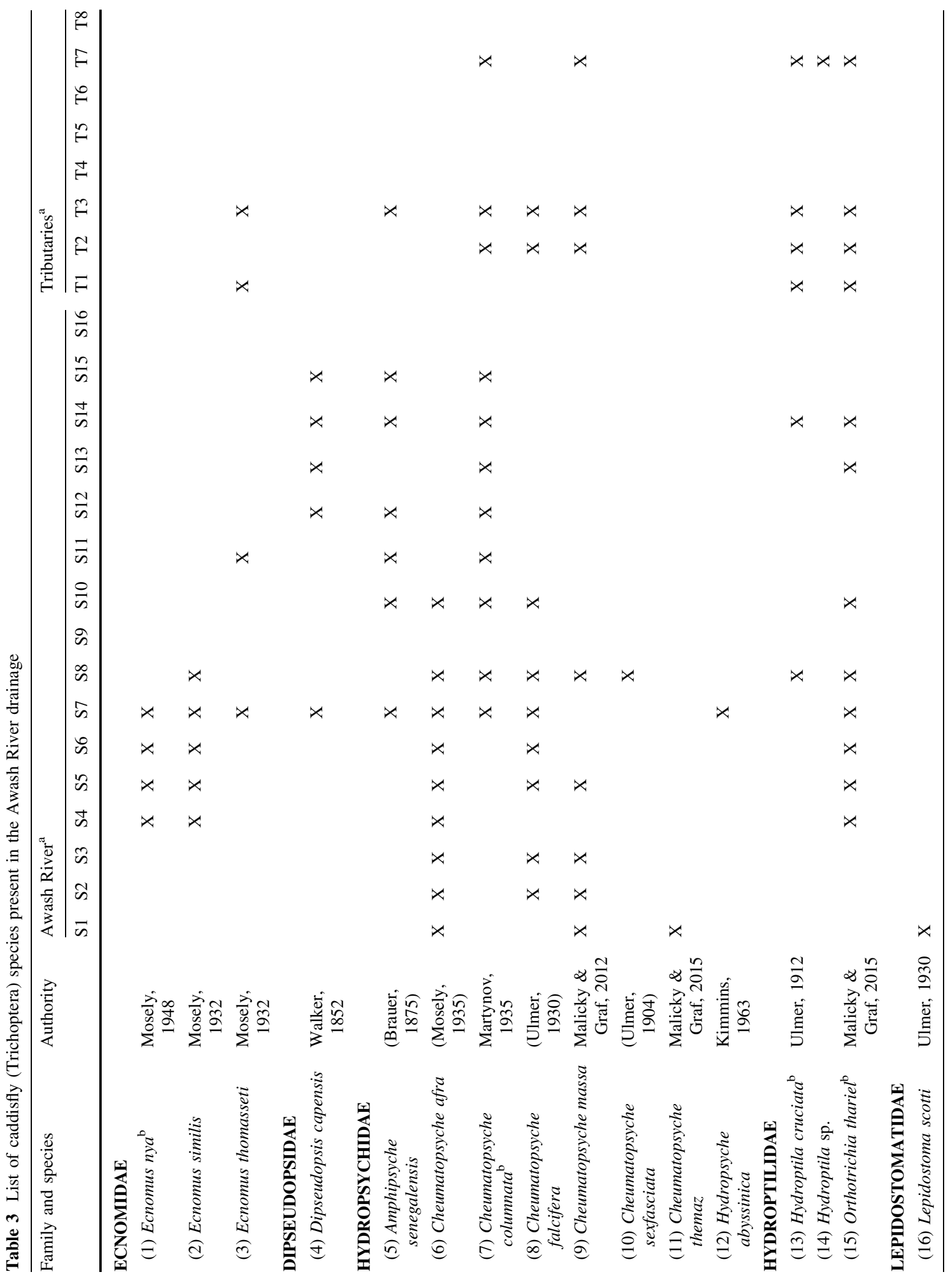




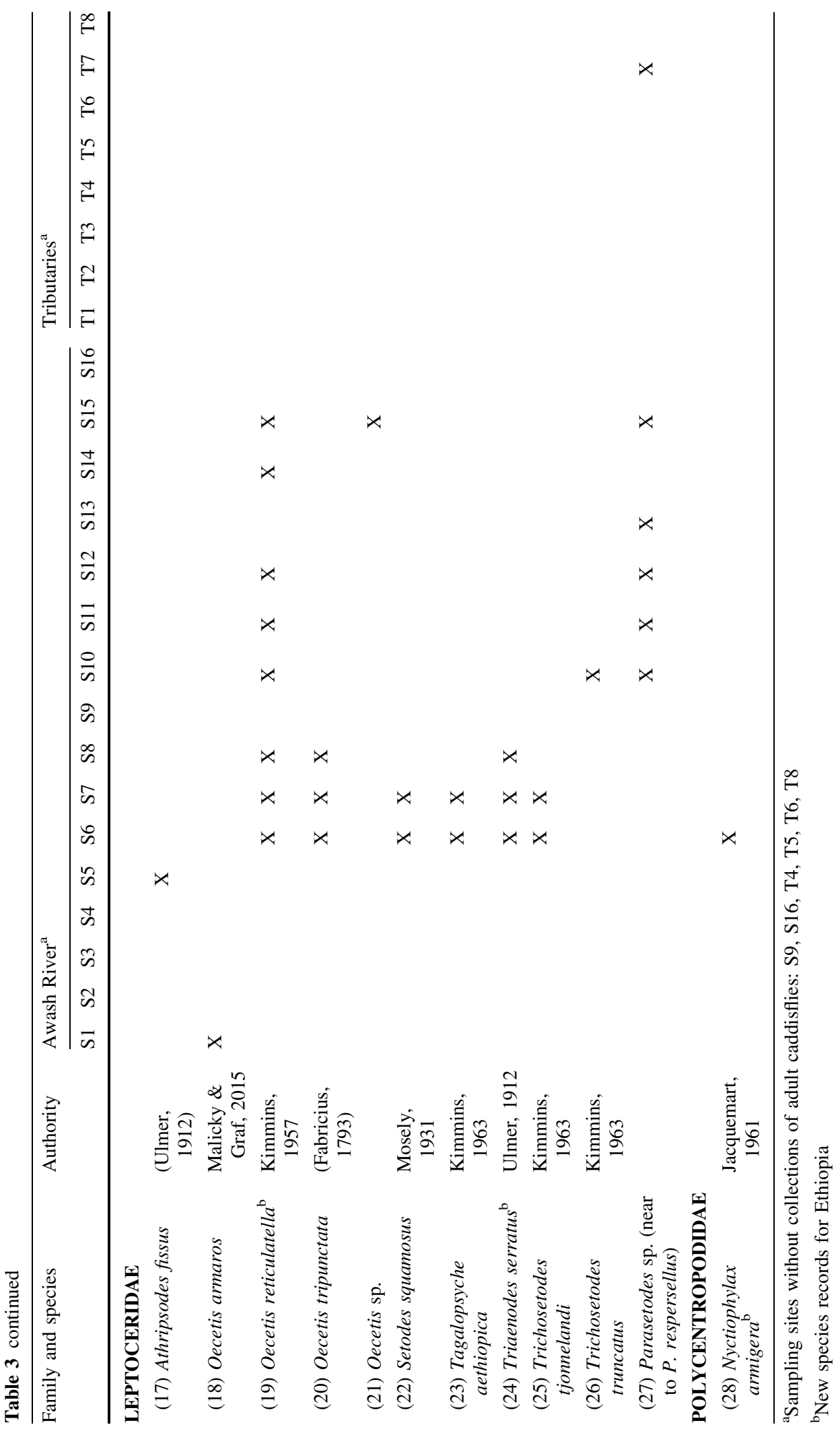


(a)

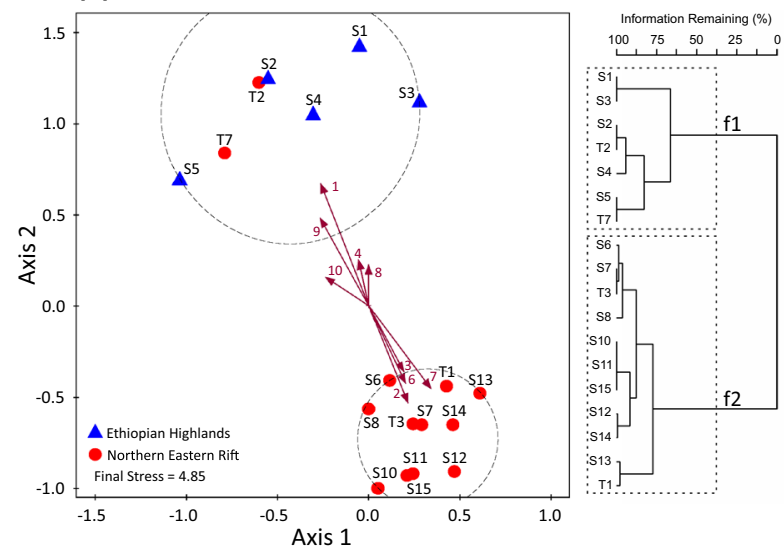

Fig. 2 Non-metric multidimensional scaling (NMDS) dendrogram and two-way cluster analysis (CA) showing zone membership for $\mathbf{a}$ fish species assemblages and $\mathbf{b}$ adult caddisfly species assemblages, based on presence/absence data and environmental variables. Group circumscription in NMDS is

27 species were recorded in the main river. We only collected adult caddisflies at four tributary sites; all of the nine species found occurred in the Awash River, except for Hydroptila sp., which was detected only in the Robit River (T7). Lepidostoma scotti, Cheumatopsyche themaz, and Oecetis armaros were found exclusively in the Chilimo Forest (S1) and were also absent from the upper tributary reaches (T2-3 and T7, above 1,367 m). Hydropsyche abyssinica, Oecetis tripunctata, Setodes squamosus, Tagalopsyche aethiopica, Triaenodes serratus, Trichosetodes tjoennelandi, and Nyctiophylax armigera showed a restricted distribution around the wetland area of the Koka Reservoir (S6-7). Orthotrichia thariel was the most widely distributed caddisfly species in the Awash drainage and was found at an altitude range of 2,003-378 m. Amphipsyche senegalensis and Dipseudopsis capensis were recorded from the main channel of the Awash at altitudes below 1,552 m. They were absent from the tributaries, except for the Borkana River at T3 (1,417 m). The two species of Hydroptila (one hitherto undescribed) were most characteristic for some of the tributaries (T1-3, T7, 1,902-482 m) and also found at S8 and S14 in the main channel (Table 3). (b)

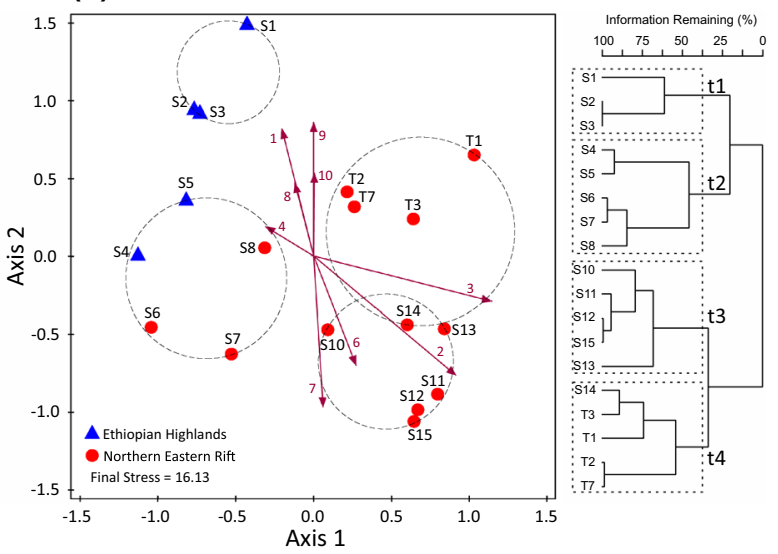

based on individual CA, with subdivisions supported by $37.5 \%$ total information-dashed line. Environmental variables used as following: 1 slope, 2 conductivity, 3 water temperature, 4 dissolved oxygen, $5 \mathrm{pH}, 6 \%$ pelal, $7 \%$ psammal, $8 \%$ microlithal, $9 \%$ mesolithal, $10 \%$ macrolithal

Faunal assemblages and zonation

The dataset to assess faunal assemblage and zonation patterns consisted of species presence/absence data for 9 fish species ( 2 non-native species were excluded) and 28 caddisfly species (Tables 2, 3), 5 environmental parameters (slope, conductivity, water temperature, dissolved oxygen, $\mathrm{pH}$ ) and dominating substrate types (pelal, psammal, akal, microlithal, mesolithal, macrolithal, megalithal) (Table 1).

Overall, both fish and caddisfly assemblages showed distinct patterns along the longitudinal gradient of the Awash River (Figs. 2, 3; Table 4).

Regarding fish, NMDS and CA revealed a clear separation of the Awash River between sites in the Ethiopian Highlands and the Northern Eastern Rift (Fig. 2a; Table 4). The difference resulted from the absence of G. aethiopica downstream of S6 and the upstream limit of G. makiensis, Clarias gariepinus, and Micropanchax antinorii at the same site. The tributaries grouped within similar faunal assemblages of the main river but did not follow the classification of freshwater ecoregions. Whilst G. aethiopica, G. dembeensis, and Labeobarbus beso were dominant in the Upper Borkana River (T2, 1,902 m) and Robit River (T7, 1,367 m), we found typical lowland species in the Lower Mille River (T1, $482 \mathrm{~m}$ ) and the Middle Borkana River (T3, 1,417 m) (Table 2). 
(a)

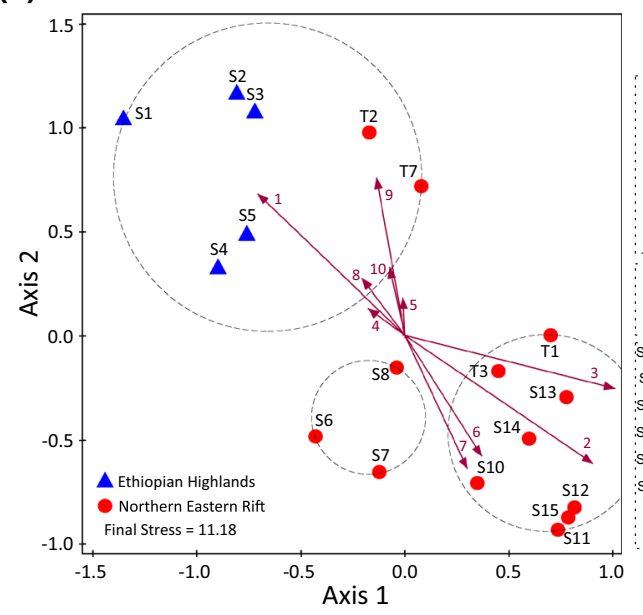

(b)

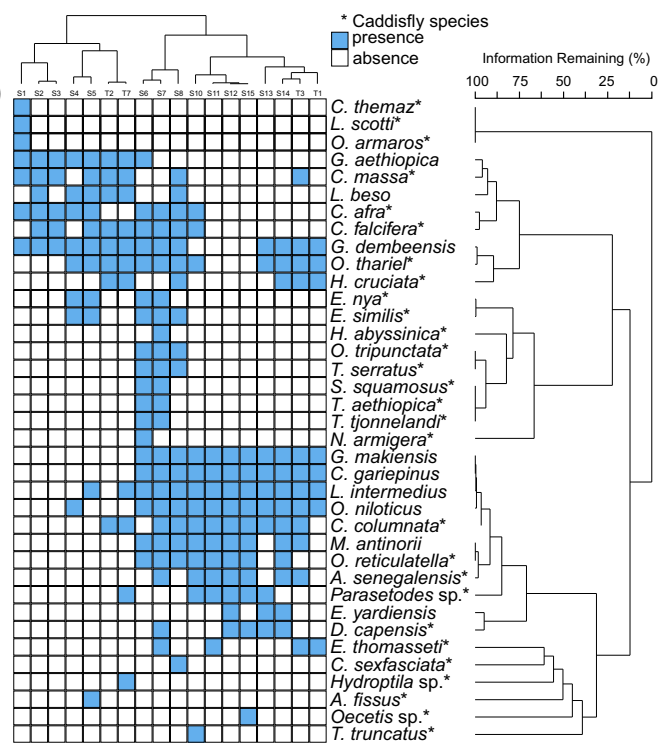

Fig. 3 Non-metric multidimensional scaling (NMDS) dendrogram and two-way cluster analysis showing zone membership for $\mathbf{a}$ a combined dataset of fish and caddisfly species and $\mathbf{b}$ twoway cluster analyses showing characteristic assemblages along the river gradient. Group circumscription is based on individual

In contrast to fish, the analyses of adult caddisfly assemblages showed a more detailed assemblage structure with four statistically distinct groups (Fig. 2b; Table 4). In detail, the first three sites (S1-3, > 2,065 m) were distinct, with Cheumatopsyche afra and Cheumatopsyche massa common to all locations, but L. scotti, C. themaz, and $O$. armaros restricted to the Chilimo Forest (S1). Sites S4 and S5 of the Ethiopian Highlands freshwater ecoregion grouped with S6-8 of the Northern Eastern Rift region. Ecnomus nya, Ecnomus similis, T. serratus, and $O$. tripunctata were most characteristic for this river stretch. The assemblage structure further downstream was dominated by D. capensis, A. senegalensis, and Parasetodes sp. The fourth group, consisting of the tributaries (T1-3, T7), was separated from the main river (except for S14) by Hydroptila cruciata and Hydroptila sp.

For the combined dataset of fish and caddisflies, the NMDS and CA revealed three distinct zones (Fig. 3), which were statistically significant (Table 4). Sampling sites S1-5 from the Ethiopian Highlands, including T2 and T7 from the Northern Eastern Rift, form a separate but heterogeneous cluster. The Upper Awash, with a length of approximately $205 \mathrm{~km}$, was two-way cluster analyses (37.5\% information retained-dashed line). Environmental variables used as following: 1 slope, 2 conductivity, 3 water temperature, 4 dissolved oxygen, $5 \mathrm{pH}, 6$ \%pelal, $7 \%$ psammal, $8 \%$ microlithal, $9 \%$ mesolithal, 10 $\%$ macrolithal

clearly distinguished from species assemblages further downstream by G. aethiopica, L. beso, C. massa, C. afra, C. themaz, L. scotti, and O. armaros. Altitude ranged from 2,389 to $1,608 \mathrm{~m}$, dissolved oxygen was close to saturation (mean $103.8 \%$ ), water temperature ranged from 15.9 to $21.1^{\circ} \mathrm{C}$, and conductivity was between 234.9 and $360.0 \mu \mathrm{S} \mathrm{cm}^{-1}$. A sharp increase in water temperature $\left(15.9-20.4^{\circ} \mathrm{C}\right)$ and conductivity (243.9-345.3 $\mu \mathrm{S} \mathrm{cm}^{-1}$ ) was recorded between $\mathrm{S} 1$ and $\mathrm{S} 2$, which were $9 \mathrm{~km}$ apart (Table 1). All sampling sites in the Upper Awash zone were characterized by a coarse substrate (microlithal to megalithal). Only at site S3 (Awash Belo), the riverbed consisted of a high percentage of psammal (20\%) and akal $(25 \%)$.

Sites S6-8, located in the Northern Eastern Rift, form a transition zone (approximately $123 \mathrm{~km}$ in length) from the mountains to the lowlands. Here, we recorded the highest species richness (nine fish and 20 caddisfly species) (Fig. 3b; Tables 2, 3). The distribution of some caddisfly species (Cheumatopsyche sexfasciata, H. abyssinica, O. tripunctata, S. squamosus, T. aethiopica, T. serratus, Trichosetodes tjonnelandi, and $N$. armigera) was even restricted to this stretch, ranging from an altitude of 1,608 to 1,214 m. Surprisingly, no fish species was particularly 
Table 4 PERMANOVA results based on Jaccard dissimilarity using presence/absence data for species assemblage structures using three datasets (fish, caddisflies, and both groups combined)

\begin{tabular}{lrllll}
\hline Factor & df & Sum Sq & $R^{2}$ & $F$ & $P$ \\
\hline Fish & 1 & & & & 0.001 \\
Zones & 16 & 2.738 & 0.793 & 61.384 & \\
$\quad$ Residuals & 3 & 0.714 & 0.207 & & 0.001 \\
Caddisflies & 14 & 3.094 & 0.571 & & 0.001 \\
$\quad$ Zones & & 2.325 & 0.429 & \\
$\quad$ Residuals & 2 & & & 9.154 & \\
Combined & 15 & 2.470 & 0.550 & & \\
$\quad$ Zones & 2.024 & 0.450 & & \\
Residuals & & & & & \\
\hline
\end{tabular}

Degrees of freedom (df), sum of squares (Sum Sq), $\left(R^{2}\right), F$-ratios, and $P$-values for the river zones (zones referring to those in Figs. 2 , 3a)

characteristic for this zone. The fish fauna included typical lowland elements such as G. makiensis, $C$. gariepinus, and M. antinorii. Garra aethiopica (typical for the Upper Awash) was still present at S6 but disappeared further downstream. In this transition zone, dissolved oxygen was close to saturation (mean $108.4 \%$, max. $124.1 \%$ at S6). Water temperature ranged from $21.1^{\circ} \mathrm{C}(\mathrm{S} 7)$ to $24.2^{\circ} \mathrm{C}$ (S6), and conductivity was between $286.7 \mu \mathrm{S} \mathrm{cm}^{-1}$ (S7) and $540.3 \mu \mathrm{S}$ $\mathrm{cm}^{-1}$ (S6). Upstream of Koka Reservoir, both water temperature and conductivity showed a sharp increase (21.1-24. $2^{\circ} \mathrm{C}$ and $360.0-540.3 \mu \mathrm{S} \mathrm{cm}^{-1}$, respectively) followed by a notable drop below the dam (24.2-21. $1^{\circ} \mathrm{C}$ and 540.3-286.7 $\mu \mathrm{S} \mathrm{cm}^{-1}$, respectively) (Table 1). The dominant substrate ranged from psammal (S6-7) to megalithal (S8).

At altitudes below 1,214 m, the Lower Awash (approximately $922 \mathrm{~km}$ in length) was dominated by widely distributed fish species such as G. makiensis, $C$. gariepinus, Oreochromis niloticus, M. antinorii, $L$. intermedius, and E. yardiensis (S12-16). Characteristic caddisfly species in this zone were $D$. capensis, $A$. senegalensis, Cheumatopsyche columnata, and Parasetodes sp. In comparison to the two other zones, dissolved oxygen concentration in the Lower Awash was lower on average (mean 92.6\%, range $65.1-110.8 \%$ ), whereas water temperature was consistently high $\left(>24^{\circ} \mathrm{C}\right)$ with a mean temperature of $27.5^{\circ} \mathrm{C}$. Similarly, conductivity exhibited the highest values in the Lower Awash, ranging from 692.8 to

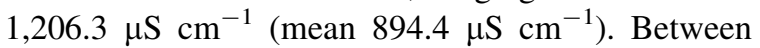
sites $\mathrm{S} 9$ and $\mathrm{S} 11$, we recorded a sharp increase in conductivity (349.7-1,206.3 $\mu \mathrm{S} \mathrm{cm}^{-1}$ ), followed by a decline to $692.8 \mu \mathrm{S} \mathrm{cm}^{-1}$ (S15). The highest conductivity measurement in the Awash drainage was recorded in Lake Gamari $\left(1,710.3 \mu \mathrm{S} \mathrm{cm}^{-1}\right)$. In the Lower Awash, pelal, psammal and microlithal were the dominant substrate types.

Faunal assemblages in the main river were not always comparable to those found in tributaries. The latter often showed limited species numbers, especially for caddisflies (Fig. 2b). Besides, the tributaries showed a different substrate composition and a substantially higher water temperature with up to $34.2^{\circ} \mathrm{C}$ at T6 (Yewuha River, 1,138 m) (Table 1).

Similar to the analyses of the fish dataset, the combined CA grouped the tributary stretches within the faunal zones of the main river (Fig. 3). Tributaries T2 (Upper Borkana River, 1,902 m) and T7 (Robit River, 1,367 m) fall within the Upper Awash, and T1 (Lower Mille River, $482 \mathrm{~m}$ ) and T3 (Middle Borkana River, 1,417 m) cluster with the Lower Awash.

\section{Indicator species}

We found that, in the Awash River, distinct species reflect the biocoenotic separation reported above (Figs. 2, 3; Tables 2, 3).

The individual analysis for fish species allowed us to distinguish two groups along the boundaries of the freshwater ecoregions. Garra aethiopica and L. beso were most characteristic for mainstem sites in the Ethiopian Highlands (S1-5) and two tributaries (T2, T7). In the Northern Eastern Rift, G. makiensis, $L$. 
Table 5 Indicator species analysis results for fish (f), caddisflies (t) and the combined (c) dataset (fish and caddisflies): Monte Carlo permutation test of significance of observed maximum indicator value (IV) for each species, based on 308 randomisations and 4,999 permutations (see Dufrêne \& Legendre, 1997)

\begin{tabular}{|c|c|c|c|c|c|c|c|c|c|c|c|}
\hline Species & Zone $^{\mathrm{a}}$ & IV & Mean & SD & $P$ & Species & Zone $^{\mathrm{a}}$ & IV & Mean & SD & $P$ \\
\hline Fish & & & & & & Combined & & & & & \\
\hline Garra aethiopica & f1 & 91.7 & 33.4 & 10.09 & $0.0010^{*}$ & Garra aethiopica & $\mathrm{c} 1$ & 75.0 & 32.0 & 10.65 & $0.0012 *$ \\
\hline Garra dembeensis & f1 & 61.1 & 48.2 & 6.22 & 0.1126 & Garra dembeensis & $\mathrm{c} 1$ & 40.0 & 38.4 & 4.64 & 0.5903 \\
\hline Garra makiensis & $\mathrm{f} 2$ & 100 & 41.6 & 8.56 & $0.0002 *$ & Garra makiensis & c2 & 50.0 & 35.4 & 9.78 & $0.0230 *$ \\
\hline Labeobarbus beso & f1 & 63.4 & 28.2 & 9.3 & $0.0132 *$ & Labeobarbus beso & $\mathrm{c} 1$ & 48.7 & 28.1 & 12.38 & 0.0568 \\
\hline $\begin{array}{l}\text { Labeobarbus } \\
\text { intermedius }\end{array}$ & $\mathrm{f} 2$ & 77.8 & 45.5 & 8.41 & $0.0024 *$ & $\begin{array}{l}\text { Labeobarbus } \\
\text { intermedius }\end{array}$ & $\mathrm{c} 2$ & 43.8 & 37.7 & 7.10 & 0.0910 \\
\hline $\begin{array}{l}\text { Enteromius } \\
\text { yardiensis }\end{array}$ & $\mathrm{f} 2$ & 27.3 & 18.4 & 8.82 & 0.2563 & $\begin{array}{l}\text { Enteromius } \\
\text { yardiensis }\end{array}$ & c3 & 37.5 & 22.7 & 11.04 & 0.1694 \\
\hline $\begin{array}{l}\text { Micropanchax } \\
\text { antinorii }\end{array}$ & $\mathrm{f} 2$ & 81.8 & 36.8 & 8.91 & $0.0024 *$ & $\begin{array}{l}\text { Micropanchax } \\
\text { antinorii }\end{array}$ & $\mathrm{c} 2$ & 57.1 & 33.0 & 10.26 & $0.0150 *$ \\
\hline Clarias gariepinus & $\mathrm{f} 2$ & 100 & 41.6 & 8.56 & $0.0002 *$ & Clarias gariepinus & c2 & 50.0 & 35.4 & 9.78 & $0.0230 *$ \\
\hline $\begin{array}{l}\text { Oreochromis } \\
\text { niloticus }\end{array}$ & $\mathrm{f} 2$ & 87.5 & 44.1 & 8.02 & $0.0008^{*}$ & $\begin{array}{l}\text { Oreochromis } \\
\text { niloticus }\end{array}$ & $\mathrm{c} 2$ & 46.7 & 36.6 & 8.63 & $0.0452 *$ \\
\hline \multicolumn{12}{|l|}{ Caddisflies } \\
\hline Ecnomus nya & $\mathrm{t} 2$ & 80.0 & 23.9 & 11.96 & $0.0072 *$ & Ecnomus nya & $\mathrm{c} 2$ & 46.7 & 23.8 & 12.70 & 0.1424 \\
\hline Ecnomus similis & $\mathrm{t} 2$ & 100.0 & 24.9 & 12.55 & $0.0004 *$ & Ecnomus similis & $\mathrm{c} 2$ & 77.8 & 25.9 & 12.94 & $0.0136^{*}$ \\
\hline Ecnomus thomasseti & $\mathrm{t} 4$ & 20.0 & 24.1 & 12.31 & 0.5765 & Ecnomus thomasseti & c3 & 19.9 & 23.9 & 12.55 & 0.4493 \\
\hline $\begin{array}{l}\text { Dipseudopsis } \\
\text { capensis }\end{array}$ & $\mathrm{t} 3$ & 36.0 & 25.2 & 12.52 & 0.2000 & $\begin{array}{l}\text { Dipseudopsis } \\
\text { capensis }\end{array}$ & $\mathrm{c} 3$ & 30.0 & 26.1 & 13.17 & 0.3065 \\
\hline $\begin{array}{l}\text { Amphipsyche } \\
\text { senegalensis }\end{array}$ & $\mathrm{t} 3$ & 45.7 & 27.7 & 10.68 & 0.0662 & $\begin{array}{l}\text { Amphipsyche } \\
\text { senegalensis }\end{array}$ & $\mathrm{c} 3$ & 51.9 & 30.2 & 11.37 & 0.0656 \\
\hline $\begin{array}{l}\text { Cheumatopsyche } \\
\text { afra }\end{array}$ & $\mathrm{t} 1$ & 45.5 & 29.1 & 9.83 & 0.1476 & $\begin{array}{l}\text { Cheumatopsyche } \\
\text { afra }\end{array}$ & $\mathrm{c} 2$ & 54.4 & 33.2 & 10.49 & 0.1248 \\
\hline $\begin{array}{l}\text { Cheumatopsyche } \\
\text { columnata }\end{array}$ & $\mathrm{t} 3$ & 45.5 & 30.6 & 7.59 & $0.0184 *$ & $\begin{array}{l}\text { Cheumatopsyche } \\
\text { columnata }\end{array}$ & $\mathrm{c} 3$ & 41.9 & 35.1 & 9.72 & 0.3185 \\
\hline $\begin{array}{l}\text { Cheumatopsyche } \\
\text { falcifera }\end{array}$ & $\mathrm{t} 2$ & 31.0 & 29 & 9.86 & 0.5181 & $\begin{array}{l}\text { Cheumatopsyche } \\
\text { falcifera }\end{array}$ & c2 & 54.4 & 33.1 & 10.45 & 0.1218 \\
\hline $\begin{array}{l}\text { Cheumatopsyche } \\
\text { massa }\end{array}$ & $\mathrm{t} 1$ & 50.0 & 28.8 & 10.02 & 0.0922 & $\begin{array}{l}\text { Cheumatopsyche } \\
\text { massa }\end{array}$ & $\mathrm{c} 1$ & 55.9 & 32.1 & 10.71 & 0.0778 \\
\hline $\begin{array}{l}\text { Cheumatopsyche } \\
\text { sexfasciata }\end{array}$ & $\mathrm{t} 2$ & 20.0 & 22.3 & 5.07 & 1.0000 & $\begin{array}{l}\text { Cheumatopsyche } \\
\text { sexfasciata }\end{array}$ & c2 & 33.3 & 16.7 & 7.52 & 0.1686 \\
\hline $\begin{array}{l}\text { Cheumatopsyche } \\
\text { themaz. }\end{array}$ & $\mathrm{t} 1$ & 33.3 & 22.2 & 4.96 & 0.1656 & $\begin{array}{l}\text { Cheumatopsyche } \\
\text { themaz. }\end{array}$ & $\mathrm{c} 1$ & 14.3 & 16.6 & 7.46 & 0.5567 \\
\hline $\begin{array}{l}\text { Hydropsyche } \\
\text { abyssinica }\end{array}$ & $\mathrm{t} 2$ & 20.0 & 22.1 & 4.89 & 1.0000 & $\begin{array}{l}\text { Hydropsyche } \\
\text { abyssinica }\end{array}$ & $\mathrm{c} 2$ & 33.3 & 16.7 & 7.56 & 0.1702 \\
\hline Hydroptila cruciata & $\mathrm{t} 4$ & 83.3 & 26.4 & 12.07 & $0.0020^{*}$ & Hydroptila cruciata & c3 & 14.1 & 28.1 & 12.48 & 1.0000 \\
\hline Hydroptila sp. & 4 & 20.0 & 22.2 & 4.92 & 1.0000 & Hydroptila sp. & $\mathrm{c} 1$ & 14.3 & 16.7 & 7.52 & 0.5529 \\
\hline Orthotrichia thariel & $\mathrm{t} 2$ & 41.7 & 30.8 & 6.48 & $0.0170^{*}$ & Orthotrichia thariel & $\mathrm{c} 2$ & 45.5 & 36.3 & 8.62 & 0.2118 \\
\hline Lepidostoma scotti & $\mathrm{t} 1$ & 33.3 & 22.2 & 4.96 & 0.1656 & Lepidostoma scotti & $\mathrm{c} 1$ & 14.3 & 16.6 & 7.46 & 0.5567 \\
\hline Athripsodes fissus & $\mathrm{t} 2$ & 20.0 & 22.2 & 4.97 & 1.0000 & Athripsodes fissus & $\mathrm{c} 1$ & 14.3 & 16.7 & 7.51 & 0.5533 \\
\hline Oecetis armaros & $\mathrm{t} 1$ & 33.3 & 22.2 & 4.96 & 0.1656 & Oecetis armaros & $\mathrm{c} 1$ & 14.3 & 16.6 & 7.46 & 0.5567 \\
\hline Oecetis reticulatella & $\mathrm{t} 3$ & 40.0 & 28.4 & 9.77 & 0.1522 & Oecetis reticulatella & c2 & 61.5 & 31.9 & 10.60 & $0.0088 *$ \\
\hline Oecetis tripunctata & $\mathrm{t} 2$ & 60.0 & 22.8 & 13.02 & $0.0434 *$ & Oecetis tripunctata & $\mathrm{c} 2$ & 100.0 & 22.7 & 11.01 & $0.0016^{*}$ \\
\hline Oecetis sp. & $\mathrm{t} 3$ & 20.0 & 22.3 & 5.04 & 1.0000 & Oecetis sp. & c3 & 12.5 & 16.7 & 7.49 & 1.0000 \\
\hline Setodes squamosus & $\mathrm{t} 2$ & 40.0 & 20.2 & 13.23 & 0.2216 & Setodes squamosus & c2 & 66.7 & 19.5 & 10.83 & $0.0196 *$ \\
\hline
\end{tabular}


Table 5 continued

\begin{tabular}{|c|c|c|c|c|c|c|c|c|c|c|c|}
\hline Species & Zone $^{\mathrm{a}}$ & IV & Mean & SD & $P$ & Species & Zone $^{\mathrm{a}}$ & IV & Mean & SD & $P$ \\
\hline $\begin{array}{l}\text { Tagalopsyche } \\
\text { aethiopica }\end{array}$ & $\mathrm{t} 2$ & 40.0 & 20.2 & 13.23 & 0.2216 & $\begin{array}{l}\text { Tagalopsyche } \\
\text { aethiopica }\end{array}$ & $\mathrm{c} 2$ & 66.7 & 19.5 & 10.83 & $0.0196^{*}$ \\
\hline Triaenodes serratus & $\mathrm{t} 2$ & 60.0 & 22.8 & 13.02 & $0.0434 *$ & Triaenodes serratus & c2 & 100.0 & 22.7 & 11.01 & $0.0016^{*}$ \\
\hline $\begin{array}{l}\text { Trichosetodes } \\
\text { tjonnelandi }\end{array}$ & $\mathrm{t} 2$ & 40.0 & 20.2 & 13.23 & 0.2216 & $\begin{array}{l}\text { Trichosetodes } \\
\text { tjonnelandi }\end{array}$ & c2 & 66.7 & 19.5 & 10.83 & $0.0196^{*}$ \\
\hline $\begin{array}{l}\text { Trichosetodes } \\
\text { truncatus }\end{array}$ & $\mathrm{t} 3$ & 20.0 & 22.3 & 5.05 & 1.0000 & $\begin{array}{l}\text { Trichosetodes } \\
\text { truncatus }\end{array}$ & $\mathrm{c} 3$ & 12.5 & 16.5 & 7.37 & 1.0000 \\
\hline Parasetodes sp. & $\mathrm{t} 3$ & 83.3 & 26.5 & 11.97 & $0.0022 *$ & Parasetodes sp. & c3 & 50.9 & 28.0 & 12.60 & 0.0550 \\
\hline $\begin{array}{l}\text { Nyctiophylax } \\
\text { armigera }\end{array}$ & $\mathrm{t} 2$ & 20.0 & 22.2 & 4.94 & 1.0000 & $\begin{array}{l}\text { Nyctiophylax } \\
\text { armigera }\end{array}$ & $\mathrm{c} 2$ & 33.3 & 16.6 & 7.42 & 0.1620 \\
\hline
\end{tabular}

*Significant at $P<0.05$ level

${ }^{\mathrm{a}}$ Zones refer to those in Figs. 2, 3a

intermedius, $M$. antinorii, C. gariepinus, and $O$. niloticus were indicative for river stretches downstream of S6 and in tributaries T1 and T3 (Table 5).

Regarding caddisflies, we distinguished four different zones. Lepidostoma scotti, C. themaz, and $O$. armaros were only recorded from the Chilimo Forest $(2,389 \mathrm{~m})$ but were not found indicative for the entire river stretch above 2,063 $\mathrm{m}$ (Table 5). Here, C. massa was most characteristic. Sites $\mathrm{S} 4-8$ were distinguished by $E$. similis and E. nya, but also by several species of the family Leptoceridae (Table 5). In the lowlands, Parasetodes sp., C. columnata, and A. senegalensis were most indicative. In contrast to the main channel, tributaries (T1-3, T7) were best characterized by $H$. cruciata.

For the combined matrix of fish and caddisflies, our analyses revealed three zones with the following indicator species (Table 5): G. aethiopica, L. beso, and $C$. massa were most indicative for the Upper Awash (mainstem) and tributaries T2 and T7, supporting the individual analyses presented above. The transition zone was best characterized by $G$. makiensis, L. intermedius, M. antinorii, C. gariepinus, $O$. niloticus, E. similis, Oecetis reticulatella, O. tripunctata, S. squamosus, T. aethiopica, T. serratus, and $T$. tjonnelandi. Based on the CA, all of the above fish species were found characteristic for the lowland fauna (Fig. 3b). Their presence at an altitude of 1,608 $\mathrm{m}$ (S6) represents their upper distribution limit in the Awash River. For the Lower Awash River, the indicator analysis found Parasetodes sp. and $A$. senegalensis most characteristic, supporting the individual analysis for caddisflies.

\section{Discussion}

The objective of our study was to explore biotic zonation patterns along the endorheic Awash River and its major tributaries in the dry season. By providing species-level information and using a combined approach of fish, adult caddisflies and environmental variables, we were able to assess the species' longitudinal distribution patterns in this tropical river, describe distinct fish and caddisfly assemblages, and detect indicator species relevant for river management.

Biotic zonation patterns and indicator species of the Awash River

Our results show that fish and caddisfly assemblages in the Awash River drainage split into two and four separate groups, respectively. The combined analyses of both organism groups clearly distinguished the species assemblages into highland and rift valley communities, which are separated by an ecotone (transition zone) with highest diversity between 1,200 and 1,600 $\mathrm{m}$. These results would lead us to propose three distinct biocoenotic zones for the Awash River. However, our findings also indicate that the Upper Awash should be further subdivided into two sections, totalling four discrete zones of the mainstem river: the source region (1a), the Upper Awash (1b), a transition zone (2), and the Lower Awash (3) (Fig. 4). 
Zone la

The Awash River's source region, located in the Chilimo Forest $(>2,389 \mathrm{~m})$, is characterized by caddisflies as fish species (G. aethiopica, G. dembeensis) were only present up to a small cascade restricting further upstream distribution (Englmaier, 2018). Three of the present caddisfly species (L. scotti, C. themaz, O. armaros), which so far are only known from Ethiopia (Malicky \& Graf, 2015; Terefe et al., 2018), exclusively occur at $S 1$ in Chilimo Forest. The headwater community consists of shredders (Lepidostoma) and predators (Leptoceridae: Oecetis). As these species inhabit clear water sections over coarse substrate and with lower $\left(<16^{\circ} \mathrm{C}\right)$ water temperatures (Table 1), they disappear in deforested areas downstream with higher proportions of fine sediment (due to erosion), less input of coarse particulate organic matter, and an increase in water temperature.

\section{Zone $1 b$}

The Upper Awash River from S2 to S5 $(2,389-1,200 \mathrm{~m})$ is more or less homogeneous regarding fish; G. aethiopica and L. beso are characteristic species for this reach. Whilst the former is omnivorous, typically scraping off food particles from various substrates (Stiassny \& Getahun, 2007), the latter is a specialized scraping feeder associated with stony substrate (Levin, 2012); both are adapted to high flow velocities and cooler water temperatures (Golubtsov et al., 2002). The cascades at Awash Kunture constitute a marked interruption in the river, affecting the upstream distribution of several other fish species. The caddisflies of this section are widely distributed throughout the highlands and already show a transition towards the rift valley communities; $C$. massa and $C$. afra are representatives for the Upper Awash zone. Except for the Chilimo Forest, the rest of the Ethiopian Highlands are under intense anthropogenic pressure due to deforestation and high livestock density (e.g. Kebede et al., 2020). Hence, although we propose that the unique caddisfly fauna in the Chilimo Forest represents a distinct section (zone 1a), the separation of the Upper Awash might also be due to the extensive loss of natural highland forests (Nyssen et al., 2015; Kebede et al., 2020). Overall, slope and mesolithal substrate were the most decisive environmental variables to separate the Upper Awash River from the lower zones.

\section{Zone 2}

The section between S6 and S8 (S9) constitutes a transition zone between the upper and lower reaches of the Awash River. Similar to conclusions of other studies (e.g. Statzner \& Higler, 1985; Thorp et al., 2006), our data showed that this ecotone offers a high habitat variability (see Table 1), which is influenced by Koka Reservoir and the natural lakes in the central part of the Main Ethiopian Rift, and exhibits the highest species numbers, particularly of caddisflies. Hence, regarding indicator species, the transition zone is predominantly characterized by caddisflies such as E. similis, O. tripunctata, and $T$. serratus, which were three of the seven indicator caddisfly species for the combined dataset. The fish species present in this zone are all members of the lowland fauna. The significant indicator values for fish in the combined dataset appear overestimated as G. makiensis, C. gariepinus, and $M$. antinorii have their upstream limit in this zone. Interestingly, the distribution boundary of these fish species is consistent with the upstream limit of crocodiles (Cott \& Pooley, 1972; Siege \& Koch, 2017), which can be seen as equally indicative for zones 2-3.

\section{Zone 3}

In the Lower Awash River (1,214-338 m), species diversity is lower than in the transition zone. Here, in the northern part of the Main Ethiopian Rift, water temperatures are consistently higher than upstream, and conductivity measurements showed a large range. The increase in conductivity between S9 and S10 probably results from the influence of the saline Lake Beseka (conductivity $>6,000 \mu \mathrm{S} \mathrm{cm}^{-1}$; Goerner et al., 2009), which flows into the Awash River through an artificial channel. The environmental parameters most decisive for the community composition of zone 3 were conductivity, water temperature, and fine-grained sediment (psammal and pelal). The species assemblages typical to the rift valley start to occur downstream of S8 (S9 for fish assemblages) but become marked after the gorge section at S10. In the Lower Awash River, G. makiensis and C. gariepinus, as well as $A$. senegalensis and $C$. columnata, are most 
widespread. Garra makiensis is predominantly rheophilic but capable of inhabiting limnetic habitats (Golubtsov et al., 2002). All fish species of the Lower Awash seem to tolerate high water temperatures with G. dembeensis showing the greatest amplitude $\left(15.9-34.2^{\circ} \mathrm{C}\right.$ ) (Tables 1,2$)$.

The low number of indicator species for such a comparably long zone is surprising. The geographically wide-spread community in the Lower Awash River presumably results from a combination of different factors, such as geotectonics, water temperature, and alternating dry periods in the history of the Main Ethiopian Rift (Bonnefille et al., 2004; Sagri et al., 2008; Foerster et al., 2014; Benvenuti \& Carnicelli, 2015). Regarding the latter, it is likely that parts of the Awash River fell dry in the past, thereby causing species to become locally extinct. After rewetting, most-probably widely distributed species with high dispersal capacities managed to recolonize the Lower Awash River. Furthermore, it must be noted that the river morphology of zone 3, which is considerably shaped by the geotectonic history of the Main Ethiopian Rift (Bonini et al., 2005; Abbate et al. 2015), is characterized by alternating sections of confined river stretches (including cataracts) and alluvial floodplains as well as low and steep gradients (Fig. 4). As such discontinuities within a similar zone may be of considerable ecological importance (Statzner \& Higler, 1986), the densification of sampling sites (e.g. including floodplain water bodies) might expose the presence of smaller patches "within a hierarchy of larger spatiotemporal patches" (Thorp et al., 2006), possibly revealing a fauna distinct from the general pattern of zone 3 , which might go hand in hand with a repetition of smaller functional process zones along the river. However, according to the serial

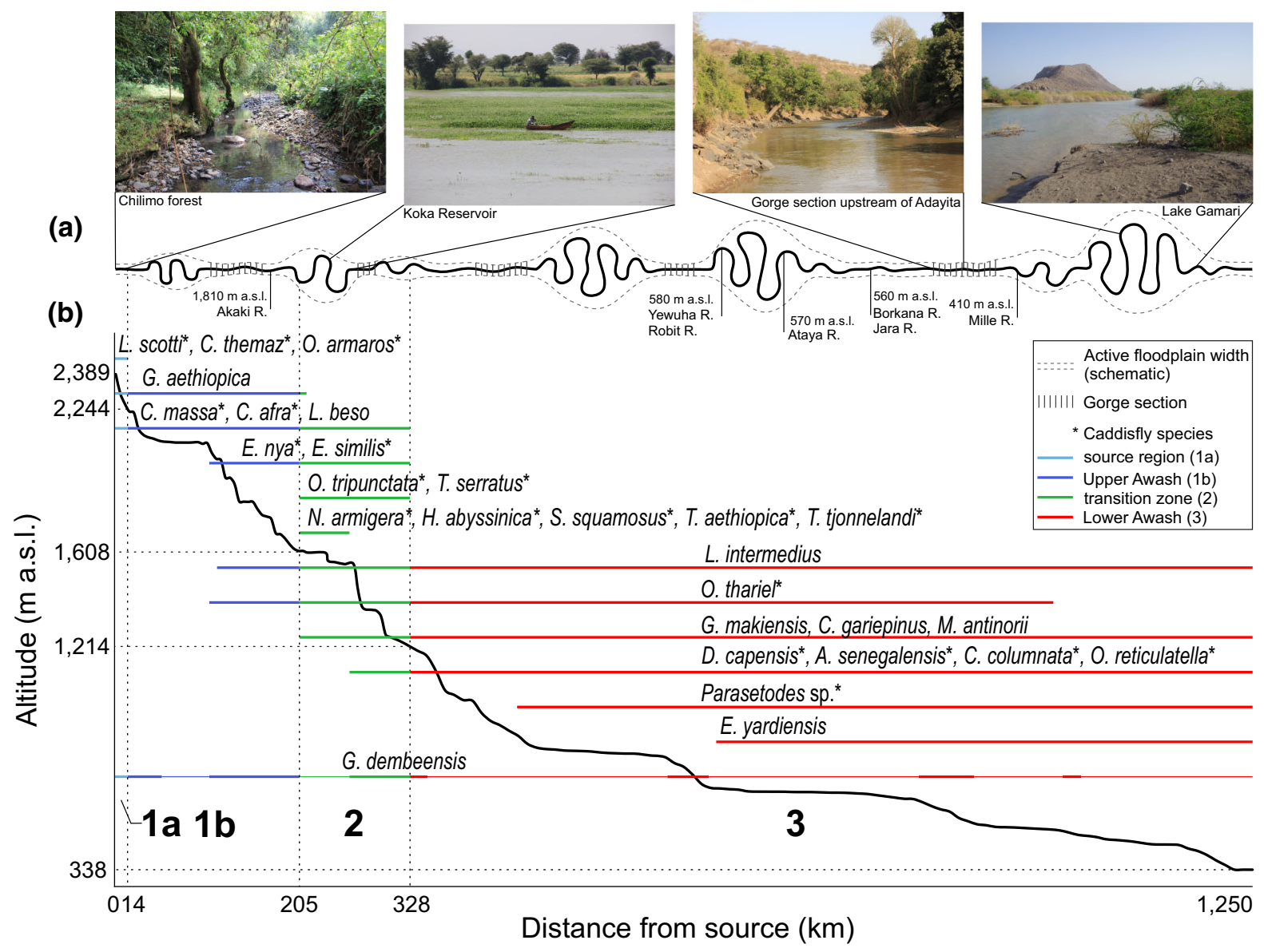

Fig. 4 Schematic representation of the longitudinal zonation of the Awash River, showing typical landscape forms, lateral (a) and longitudinal (b) river gradient, and characteristic fish and caddisfly species 


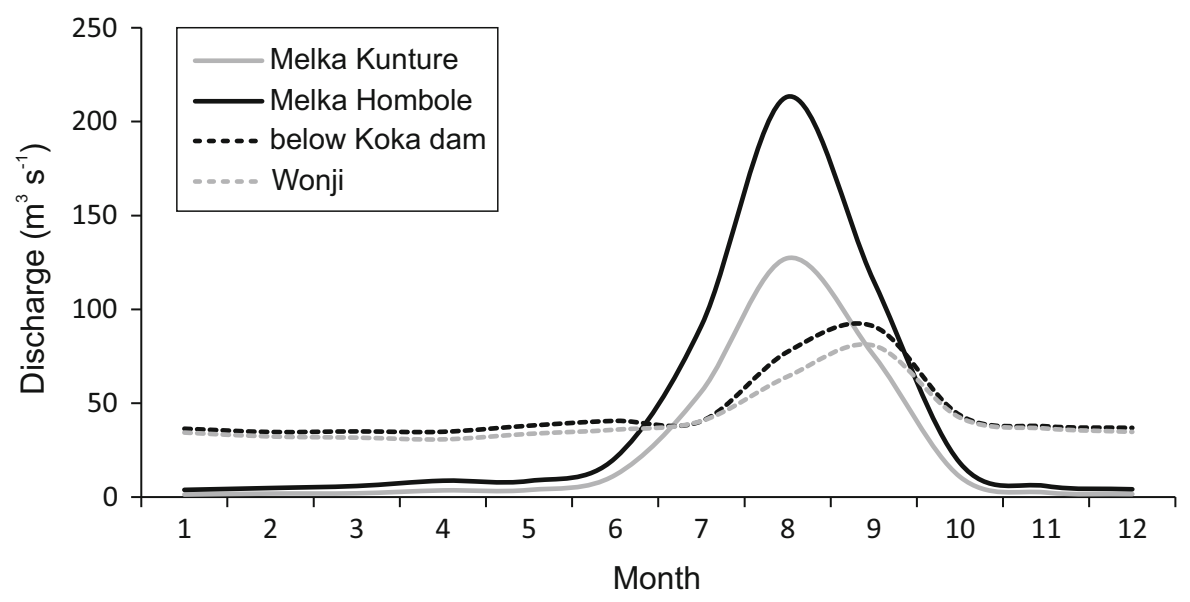

Fig. 5 Mean monthly flow magnitude measured at four gauging stations on the Awash River-in downstream direction: Melka Kunture ( $8^{\circ} 42^{\prime} 15^{\prime \prime}$ N, $38^{\circ} 36^{\prime} 22^{\prime \prime}$ E), Melka Hombole $\left(8^{\circ} 22^{\prime} 45^{\prime \prime} \mathrm{N}, 38^{\circ} 46^{\prime} 46^{\prime \prime} \mathrm{E}\right.$; upstream of Koka Reservoir),

discontinuity concept (Ward \& Stanford, 1983, 1995), the influence of Koka Reservoir and the other impoundments (see Fig. 1) may be another reason for the rather long and homogeneous Lower Awash River section. Not only do these dam structures disrupt the longitudinal river gradient and constitute a recent upstream dispersal barrier, but they also homogenize the flow regime downstream of the reservoir (Fig. 5). These flow regime modifications may have caused changes within the community in the Lower Awash River (e.g. Junk et al., 1989; Winemiller, 2004; Hayes et al., 2018). Besides, the reservoirs may cause, for example, through plankton production (Degefu et al., 2011), considerable alterations in the food resources downstream. In the reservoir itself, the accumulation of fine sediments (Kropáček et al., 2016) may have implications for the aquatic fauna (Jones et al., 2007).

\section{Tributaries}

The tributaries of the Northern Eastern Rift (T1-3, T7) exhibit a pattern distinctive of that from the mainstem river zones. Their substrate composition is similar to that of the Upper Awash, dominated by coarse gravel to boulders. However, their riverbeds are much wider and the water temperatures are higher compared to the mainstem Awash River at similar altitudes (Table 1). In the Middle Borkana River (T3) and the Yewuha River (T6) water temperatures exceeded $30^{\circ} \mathrm{C}$, which is possibly linked to the presence of hot thermal below Koka Dam ( $8^{\circ} 28^{\prime} 6^{\prime \prime}$ N, 39 $9^{\circ} 9^{\prime} 33^{\prime \prime}$ E), Wonji ( $8^{\circ} 28^{\prime} 24^{\prime \prime}$ $\left.\mathrm{N}, 39^{\circ} 12^{\prime} 48^{\prime \prime} \mathrm{E}\right)$. Data source Ethiopian Ministry of Water, Irrigation and Electricity (2019)

springs. Caddisfly assemblages tend to be similar to the lowland communities, despite an impressive altitude range of the tributaries (482-1,902 m). Also, fish assemblages show a similar pattern to the Lower Awash River, with the exception of T2 and T7, which are associated to the Ethiopian Highlands. The indicator species of these streams, H. cruciata, is apparently associated with coarse substrate and high flow velocities, and is widely distributed throughout Africa (Botosaneanu, 2002).

Several authors have contributed observations from tropical rivers for fish (e.g. Ibanez et al., 2007; Araújo et al., 2009; Payne et al., 2010; Fitzgerald et al., 2018) and caddisflies (e.g. Malicky \& Chantaramongkol, 1993; Chaibu, 2000; de Moor et al., 2000; de Moor, 2011), but no common classification of stream sections into general zonation concepts has yet been achieved (Aarts \& Nienhuis, 2003). This might be due to the fact that the predictability of zonation patterns becomes more difficult above the ecoregional level (Thorp et al., 2006). In the Awash River, we found that species assemblages in the mainstem were mostly distinct between the two ecoregions but were the same within a single ecoregion (with the exception of the transition zone for the caddisfly dataset). Depending on the dataset used for the analyses, the tributarieslocated at the border of both ecoregions-were either grouped with the lowland sites (combined and fish datasets) or showed a separate group (caddisfly dataset). Regarding the first, however, the assemblage 
of the Upper Borkana River (T2) and Robit River (T7) was clustered with the Upper Awash River in the highlands. Nevertheless, it cannot be completely elucidated if the grouping of sites resulted primarily from their location in the ecoregion or along a steep altitudinal gradient (however, one is not completely independent of the other anyways). This raises the question if precise definitions of zones, such as rhithron and potamon (Illies \& Botosaneanu, 1963) are needed and applicable on a global scale (without introducing several specific exceptions). Clearly defined river sections might be applied individually depending on the local characteristics of the respective river. In general, the longitudinal river zonation of biota depends on type, range and interaction of various environmental and/or biotic gradients (e.g. Hawkes, 1975; Malicky \& Chantaramongkol, 1993; Araújo et al., 2009). The stronger the gradient, the stronger the demarcation between biocoenoses will be, resulting in distinct zones or patches with more or less sharp transitions. Independent from geographic location and faunal composition, more or less well separated species assemblages will be visible.

Overall, river zonation and measurements of associated indicator species can provide vital information to inform integrated river basin management (Lorenz et al., 2001). In this regard, knowledge on fish and caddisfly diversity, for example, can be used for ecological status assessments (e.g. Lakew \& Moog, 2015; Alemneh et al., 2019).

Insights into species diversity

The present findings are one of the first studies to investigate the longitudinal zonation patterns of fish and caddisfly assemblages in the Afrotropical realm on the species level. The following section, therefore, discusses the findings from a biodiversity perspective.

\section{Fish fauna}

In comparison to the adjacent Omo-Turkana (79 species), Blue Nile (64 species), White Nile (106 species) and Wabe Shebelle (31 species) drainage systems (Golubtsov \& Mina, 2003), the fish diversity in the Awash was exceptionally low (11 species) (see Golubtsov et al., 2002). Furthermore, our results show that the fish fauna is dominated by cyprinids of the genera Labeobarbus, Garra and Enteromius. Except for the widespread $O$. niloticus (Nilo-Sudan), $C$. gariepinus (Pan-African), G. dembeensis (Nilo-Sudan), and L. intermedius (Nilo-Sudan), the fish species are endemic to Ethiopia (Golubtsov et al., 2002; de Graaf et al., 2007; Stiassny \& Getahun, 2007; Englmaier et al., 2020). Indeed, it has been recognized that the northern and central parts of the Main Ethiopian Rift exhibit a fish species composition distinct from the Nilo-Sudan ichthyofaunal province, with affinities to the freshwater ecoregions of the Ethiopian Highlands and the Western Red Sea Drainages (Roberts, 1975; Paugy, 2010). Characteristic families for the Nilo-Sudan ichthyofauna (e.g. Characidae, Mochokidae, Mormyridae, Tetraodontidae) are absent from the Awash; others (e.g. Bagridae, Claroteidae) are extinct (Stewart \& Murray, 2017). Two species reported earlier from the Awash, E. akakianus and Aphanius dispar (see Golubtsov et al., 2002), were not found in the present surveys. Their current status needs clarification.

The highland fauna with G. aethiopica (morphologically close to G. quadrimaculata), G. dembeensis, and $L$. beso is similar to that of the Upper Blue Nile (Golubtsov et al., 2002). The genera Garra and Labeobarbus are common in the headwaters of all Ethiopian drainages (Habteselassie, 2012). Conversely, however, headwater groups found elsewhere in tropical or southern Africa including Afronemacheilus, Amphilius, Chiloglanis, Enteromius, Kneria or Parakneria (Balon \& Stewart, 1983; Skelton, 2001; Bills et al., 2012; Prokofiev \& Golubtsov, 2013; Schmidt, 2014) are absent from the Upper Awash.

The Lower Awash is inhabited by widely distributed generalists like O. niloticus, C. gariepinus, and $L$. intermedius. Others such as E. yardiensis, $M$. antinorii, and G. makiensis are highly specialized and show affinities to the Nile drainage (Englmaier et al., 2020), the central East African rift (Golubtsov et al., 2002) and the Arabian Peninsula (Englmaier et al., unpublished data) respectively.

\section{Caddisfly fauna}

Only 92 species (9 families) of caddisflies are known so far from Ethiopia (Tobias \& Tobias, 2008; Terefe et al., 2018; Morse, 2020). Given the higher diversity in South Africa (253 species; de Moor \& Day, 2013) and Madagascar (500 species; Benstead et al., 2003), the Ethiopian fauna appears to be either poorly 
investigated (Terefe et al., 2018) or greatly impoverished. We collected only 28 species ( 7 families) within the entire Awash drainage, although nearly 1,250 km of the main river and seven tributaries were surveyed. Kimmins (1963), Malicky \& Graf $(2012,2015)$ and Terefe et al. (2018) reported 14 additional species, increasing the number to 42 species in the Awash drainage. However, this number is still low if compared to other tropical rivers such as the Mae Klang Catchment (Northern Thailand) with 171 species (Malicky \& Chantaramongkol, 1993; Chaibu, 2000; Chaibu et al., 2002; Malicky, 2014).

In the Awash catchment, species of the families Hydropsychidae and Leptoceridae were most widely encountered. These families make up nearly two thirds of all species. Most species in the Awash are representatives of the Afrotropical region. Some caddisfly species cover huge geographic areas, for example, H. cruciata (Cape Verdes, South Africa, Madagascar, Arabian Peninsula), A. senegalensis (West Africa, Egypt to South Africa), D. capensis and E. similis (West Africa, Ethiopia, South Africa), $O$. tripunctata (wide distribution; Portugal to Bali; Malicky, 2005), or elements of Central Africa like $E$. nya, $N$. armigera, O. reticulatella (Kjærandsen \& Andersen, 1997; Olah \& Johanson, 2008; Morse, 2020). Others are, as far as known today, Ethiopian endemics, including L. scotti, O. thariel, O. armaros, H. abyssinica, C. massa, and C. themaz (Malicky \& Graf, 2012, 2015; Terefe et al., 2018).

Characteristic species of higher elevations (Upper Awash, $>1,608 \mathrm{~m}$ ) are L. scotti, O. armaros, $C$. themaz, C. afra, Cheumatopsyche falcifera, C. massa, E. nya, and E. similis. Their distribution was, however, not uniform. The first three species solely inhabited the river's source region in Chilimo Forest (Terefe et al., 2018). They apparently disappear in deforested areas as we did not record them further downstream or in the upper sections of tributaries. Nevertheless, species diversity in the forested highland areas might be higher than we recorded. Malicky \& Graf (2015), for example, described species such as Hellyethira marioch, Stactobia ruthiel, Orthotrichia gudiel, and Athripsodes druchas from a small forest creek north of Addis Ababa. The genus Lepidostoma is a characteristic element of the highlands in several African regions (Mosely, 1939; Marlier, 1954). The other species peculiar for the Upper Awash region-C. afra,
C. falcifera, C. massa, E. nya, and E. similis-are more widely distributed throughout Africa and seem to be insensitive to the loss of natural forest cover. Despite being characteristic for the Ethiopian Highlands, those species present a transition to the rift valley community.

Some species, such as $O$. tripunctata, $T$. serratus, $S$. squamosus, T. aethiopica, and T. tjonnelandi, occurred exclusively in the wetland area of Koka Reservoir. Here, the river morphology changes sharply and the area becomes comparably flat, the river slope and flow velocity are reduced, fine sediment is deposited, and filter feeders with ultra-fine nets (D. capensis, A. senegalensis) occur here for the first time. Indeed, studies from lakes and reservoirs (Mosely, 1931; Kimmins, 1963) suggest that T. aethiopica, S. squamosus, T. tjonnelandi, and T. aethiopica prefer limnetic habitats and fine substrates. Aside from these four species, Kimmins (1963) found six other species in the area around Koka Reservoir: C. afra, $C$. sexfasciata, $H$. abysinnica, D. capensis, E. similis and A. senegalensis. As mentioned earlier, the section around Koka Reservoir apparently represents an ecotone where highland and lowland species overlap and coexist. With 29 species currently known from the central part of the Main Ethiopian Rift, this river zone shows a high diversity for the region as it contains elements from the adjacent freshwater ecoregions.

In the Lower Awash River, the number of caddisfly species is reduced (comparable to fish); some species which occur around Koka Reservoir are distributed further downstream, indicating a considerable influence of the reservoir. Members of the rift valley community with a slight overlap to the highlands consist of $O$. reticulatella, D. capensis, A. senegalensis, and C. columnata. In this zone, the river alternately flows through confined reaches and extensive wetlands (Fig. 4). The smooth stream gradient is frequently interrupted by cataracts, resulting in associated changes in substrate composition from fine to large substrates or bedrock. In stony sections, including the tributaries in the Northern Main Ethiopian Rift, we found $H$. cruciata. Though faunal elements of the lowlands are comparable with other river systems in the Afrotropical region (e.g. Gibon \& Statzner, 1985; de Moor et al., 2000) the fauna in the Awash River is largely impoverished. 
Drivers of diversity

Both, fish and caddisflies exhibited an exceptionally low diversity in the Awash River catchment. Reasons for the apparently low species numbers might be related to the following characteristics.

\section{Anthropogenic impacts}

The Awash River is under extreme human pressure. Deforestation, plantations of Eucalyptus and Prosopis, intensive agricultural use and overgrazing by livestock linked with high nutrient input and erosional processes, as well as industrial and domestic water pollution, are common (Degefu et al., 2013; Keraga et al., 2019). However, this affects mainly the highlands. In the Lower Awash River, livestock is reduced and agriculture is focused at some few irrigated areas. Anthropogenic degradation might therefore be a reason for the low diversity in the Ethiopian Highlands more so than in lowland areas. Studies of reference streams in near-natural environments are not known from Ethiopia, and generally, studies on tropical caddisflies at species level along comparable stretches are rare (e.g. Chaibu et al., 2002).

\section{Geotectonic activities}

Geological data give evidence for frequent tectonic and volcanic activities in the history of the Main Ethiopian Rift (Benvenuti et al., 2002; Abbate et al., 2015). These events presumably not only affected the geomorphology and connectivity of the Paleo-Awash (Sagri et al., 2008) but also the distribution of fish species (Beshera \& Harris, 2014; Englmaier et al., 2020). Moreover, thermal springs may have considerable influence on the water temperature at higher altitudes (e.g. Middle Borkana River, $31.2^{\circ} \mathrm{C}$ at $1,417 \mathrm{~m}$ ), possibly also affecting species composition (Lamberti \& Resh, 1985).

\section{River network}

The Awash River is an endorheic drainage system, lacking the marine/estuary ecotone. In contrast to large endorheic drainages of Africa such as the Omo (Ethiopia) and the Chad rivers (Central Africa), the Awash does not flow into a large lake basin that supports a rich fauna. Lake Abbe in the Afar Depression is highly saline and an extreme habitat for fish and caddisflies.

\section{Climatic characteristics}

The Awash drainage system is located in an area subject to extreme climatic conditions. It is distinguished by high temperatures and exceptionally low precipitation (Fazzini et al., 2015). In the Afar region, the high water temperatures might be a limiting factor for species distribution, potentially exceeding the ecological tolerance of several species. Paleoclimatic and paleohydrological studies have shown frequent lake level changes in the Main Ethiopian Rift (Grove et al., 1975; Le Turdu et al., 1999; Sagri et al., 2008; Benvenuti \& Carnicelli, 2015), suggesting a long history of unstable environmental conditions. During dry periods in the past, the Awash River possibly turned ephemeral, thereby limiting faunal persistence. Regarding caddisflies, it seems likely that widely distributed species with high dispersal capacities and broad ecological ranges managed to recolonize old habitats. The specialized fauna of Chilimo Forest, in contrast, indicates that more stable environmental conditions persisted over longer periods.

\section{Possible methodological limitations}

We sampled fish and caddisflies over three different years and periods (at the start, middle and end of the dry season) (Table 1). Although this did not seem to influence our results, the effects of temperature or river flow could have influenced species detection. Besides, we investigated species diversity during the dry season only and thereby did not cover the aspect of seasonality. Even though phenological investigations in tropical streams indicate long flight periods for most caddisflies throughout the year (e.g. Malicky, 2019), little is known about flight periods of African species. Kimmins (1963) found A. senegalensis during March and April, and Mosely (1948) detected specimens in January and June. However, substantial knowledge gaps regarding seasonality remain. The same is true regarding diurnal activity. This might have increased the change of missing caddisfly species, for example, those which are only active late in the night or early in the morning, in addition to the fact that most sites were only investigated once. Especially the fauna of 
cataract sections in the Lower Awash needs to be investigated in detail but sampling efforts were limited due to inhibited accessibility.

The best explanation for the species-poor situation of caddisflies in the Awash River is, however, the general poverty of the Afrotropical caddisfly fauna as a whole, which cannot be explained at the present state of knowledge. Exact numbers of species cannot be given because of taxonomic uncertainty of described species, and more new species await discovery. Many widespread caddisfly genera or families are either lacking in tropical Africa (e.g. Rhyacophilidae which are present with hundreds of species in Asia and even non-tropical Europe, or the genus Psychomyia with well over 70 species in tropical Asia) or represented only by very few species (e.g. 1 species of Stenopsyche, as compared to more than 50 only in western China). Except for some species-poor endemic families or genera in southern Africa (Scott 1986, 1993), only a few widespread species-rich genera are well represented in tropical Africa such as Leptoceridae, Ecnomus, Cheumatopsyche, Chimarra, or Dipseudopsis. Rivers in Asia and Europe contain by far more species than the Awash River. For example, 91 species are reported for the Mae Nam Ping in Thailand over a stretch of $120 \mathrm{~km}$ (Chaibu \& Chantaramongkol, 1999; Chaibu, 2000; Chaibu et al., 2002; Malicky, 2014), 98 species for the Drava River at the border between Hungary and Croatia (Uherkovich \& Nógrádi, 2018), 81 species in the Po River in Italy (Bertuetti et al., 2001), or 61 species in the middle part of Danube River in Central Europe (Malicky, 2014).

\section{Conclusion}

Our study showed that, in the tropical endorheic Awash River, fish and caddisfly assemblages sampled during the dry season are clearly clustered into highland (Upper Awash) and rift valley (Lower Awash) communities, separated by an ecotone (transition zone) with highest species diversity. The fish and caddisfly assemblages are congruent in their overall distribution patterns, which reflect changes in altitude and jumps between ecoregions. Only caddisflies exhibited a narrower niche in the headwaters, separating the Upper Awash River into a forested and a deforested zone.
Furthermore, we described the most indicative species for the biocoenoses along the mainstem river as well as its tributaries. As species-specific bioindicators are rare or absent in most of the Afrotropical region, these results may constitute a fundamental element for the management of the Awash River and beyond.

Compared to other drainage basins in Eastern Africa, the Awash River is rather species poor, which may result from various natural and anthropogenic factors. Nevertheless, the highland forests seem to be centres of specialized caddisfly species with smallscale distribution, and the Awash lowlands harbour endemic fish species restricted to the Main Ethiopian Rift.

Possible limitations to our study include the aspects of sampling timing and lack of seasonality, which may have oversimplified our results. More studies are needed to understand spatio-temporal effects in distribution patterns in the Afrotropical region.

In summary, we found that a combined approach of fish and caddisflies proved to be a suitable method for identifying longitudinal and regional characteristics of fluvial ecosystems in tropical environments. In the future, East African research must focus on taxonomy, ecology and distribution patterns on species level. Such investigations are urgently needed to foster the development of reliable systems for assessing and monitoring the integrity of tropical river systems and their biodiversity.

Acknowledgements Fieldwork was conducted under the auspices of the LARIMA Project (Project Number 106) funded by the Austrian Partnership Programme in Higher Education and Research for Development (APPEAR) of the Austrian Development Cooperation (ADC) and the Austrian Agency for International Cooperation in Education and Research (OeAD). Field research was supported by the National Fisheries and Aquatic Life Research Center (NFALRC) and the Ethiopian Institute of Agricultural Research (EIAR) (Permit Numbers 1.9/0323/2017, 1.9/3196/ 2018, 1.9/0336/2019). G.K.E. was supported by a Grant from the Doctoral Academy Graz, Ecology and Evolution in Changing Environments (EECE), University Graz. D.S.H. benefited from a Ph.D. Grant sponsored by Fundação para a Ciência e a Tecnologia I.P. (FCT), Portugal (PD/BD/114440/ 2016). CEF is a research unit funded by FCT (UID/AGR/00239/ 2013). We are thankful to the staff members of Ambo University and the National Fisheries and Aquatic Life Research Centre, Sebeta for providing logistics during field work. Asefa Keneni, Moges Kidane Biru (Ambo University), and Gerold Winkler (IPGL, BOKU-Vienna) provided valuable comments and support to the study. The invaluable taxonomical assistance of 
François-Marie Gibon (Olemps, France) is appreciated. We thank the local communities along the Awash River for providing access to the sampling localities.

Data availability Data are available from the corresponding authors upon reasonable request.

\section{Compliance with ethical standards}

Conflict of interest The authors declare no conflict of interest.

Open Access This article is licensed under a Creative Commons Attribution 4.0 International License, which permits use, sharing, adaptation, distribution and reproduction in any medium or format, as long as you give appropriate credit to the original author(s) and the source, provide a link to the Creative Commons licence, and indicate if changes were made. The images or other third party material in this article are included in the article's Creative Commons licence, unless indicated otherwise in a credit line to the material. If material is not included in the article's Creative Commons licence and your intended use is not permitted by statutory regulation or exceeds the permitted use, you will need to obtain permission directly from the copyright holder. To view a copy of this licence, visit http://creativecommons.org/licenses/by/4.0/.

\section{References}

Aarts, B. G. W. \& P. H. Nienhuis, 2003. Fish zonations and guilds as the basis for assessment of ecological integrity of large rivers. Hydrobiologia 500: 157-178.

Abbate, E., P. Bruni \& M. Sagri, 2015. Chapter 2: geology of Ethiopia: a review and geomorphological perspectives. In Billi, P. (ed.), Landscapes and Landforms of Ethiopia, World Geomorphological Landscapes. Springer, Dordrecht: 33-64.

Abell, R., M. L. Thieme, C. Revenga, M. Bryer, M. Kottelat, N. Bogutskaya, B. Coad, N. Mandrak, S. C. Balderas, W. Bussing, M. L. J. Stiassny, P. Skelton, G. R. Allen, P. Unmack, A. Naseka, R. Ng, N. Sindorf, J. Robertson, E. Armijo, J. V. Higgins, T. J. Heibel, E. Wikramanayake, D. Olson, H. L. López, R. E. Reis, J. G. Lundberg, M. H. Sabaj Pérez \& P. Petry, 2008. Freshwater ecoregions of the world: a new map of biogeographic units for freshwater biodiversity conservation. BioScience 58: 403-414.

Alemneh, T., A. Ambelu, B. F. Zaitchik, S. Bahrndorff, S. T. Mereta \& C. Pertoldi, 2019. A macroinvertebrate multimetric index for Ethiopian Highland streams. Hydrobiologia 843: 125-141.

Allaya, W., 2003. Description de cinq larves de Trichoptères du genre Hydropsyche récoltées en Tunésie. Braueria 30: 21-22.

Anderson, M. J., 2001. A new method for non-parametric multivariate analysis of variance. Austral Ecology 26: $32-46$.

Araújo, F. G., B. C. T. Pinto \& T. P. Teixeira, 2009. Longitudinal patterns of fish assemblages in a large tropical river in southeastern Brazil: evaluating environmental influences and some concepts in river ecology. Hydrobiologia 618: 89-107.

Balian, E. V., H. Segers, C. Lévêque \& K. Martens, 2008. The Freshwater Animal Diversity Assessment: an overview of the results. Hydrobiologia 595: 627-637.

Balon, E. K. \& D. J. Stewart, 1983. Fish assemblages in a river with unusual gradient (Luongo, Africa: Zaire system), reflections on river zonation, and description of another new species. Environmental Biology of Fishes 9: 225-252.

Benstead, J. P., P. H. De Rham, J. L. Gattolliat, F. M. Gibon, P. V. Loiselle, M. Sartori, J. S. Sparks \& M. L. J. Stiassny, 2003. Conserving Madagascar's freshwater biodiversity. BioScience 53: 1101-1111.

Benvenuti, M. \& S. Carnicelli, 2015. The geomorphology of the lake region (Main Ethiopian Rift): the record of paleohydrological and paleoclimatic events in an active volcanotectonic setting. In Billi, P. (ed.), Landscapes and Landforms of Ethiopia, World Geomorphological Landscapes. Springer, Dordrecht: 289-305.

Benvenuti, M., S. Carnicelli, G. Belluomini, N. Dainelli, S. Di Grazia, G. A. Ferrari, C. Iasio, M. Sagri, D. Ventra, B. Atnafu \& S. Kebede, 2002. The Ziway-Shala Lake Basin (main Ethiopian rift, Ethiopia): a revision of basin evolution with special reference to the Late Quaternary. Journal of African Earth Sciences 35: 247-269.

Bertuetti, E., O. Lodovici \& M. Valle, 2001. I tricotteri del Fiume Po (Insecta, Trichoptera). Rivista del Museo civico di Scienze Naturali "E. Caffi" di Bergamo 20: 87-97.

Beshera, K. A. \& P. M. Harris, 2014. Mitochondrial DNA phylogeography of the Labeobarbus intermedius complex (Pisces, Cyprinidae) from Ethiopia. Journal of Fish Biology 85: 228-245.

Bills, K., P. Skelton \& F. Almeida, 2012. Survey of the Fishes of Upper Okavango River System in Angola. Investigational Report No. 73. South African Institute for Aquatic Biodiversity (SAIAB).

Bonini, M., G. Corti, F. Innocenti, P. Manetti, F. Mazzarini, T. Abebe \& T. Pecskay, 2005. Evolution of the Main Ethiopian Rift in the frame of Afar and Kenya rifts propagation. Tectonics 24: 1-21.

Bonnefille, R., R. Potts, F. Chalie, D. Jolly \& O. Peyron, 2004. High-resolution vegetation and climate change associated with Pliocene Australopithecus afarensis. Proceedings of the National Academy of Sciences of the United States of America 101: 12125-12129.

Botosaneanu, L., 2002. A classical case of insular radiation: the Hydroptila species of La Réunion. Proceedings of the 10th International Symposium on Trichoptera. Nova Supplementa Entomologica, Keltern 15: 323-330.

Chaibu, P., 2000. Potential use of Trichoptera as water pollution biomonitoring in Ping River, Chiang Mai. Doctoral Thesis. Chiangmai University, Chiang Mai.

Chaibu, P. \& P. Chantaramongkol, 1999. Caddisflies (Trichoptera) from the Upper Ping River, northern Thailand. In Proceedings of the 9th International Symposium on Trichoptera. Faculty of Science, Chiangmai University, Thailand: 53-54.

Chaibu, P., P. Chantaramongkol \& H. Malicky, 2002. The caddisflies (Trichoptera) of the River Ping, northern Thailand, with particular reference to domestic pollution. Nova Supplementa Entomologica, Keltern 15: 331-432. 
Clausen, R. \& R. York, 2008. Global biodiversity decline of marine and freshwater fish: a cross-national analysis of economic, demographic, and ecological influences. Social Science Research 37: 1310-1320.

Cott, H. B. \& A. C. Pooley, 1972. Crocodiles, the status of crocodiles in Africa, Volume 2. International Union for Conservation of Nature and Natural Resources 33: 1-98.

Darwall, W., V. Bremerich, A. De Wever, A. I. Dell, J. Freyhof, M. O. Gessner, H. P. Grossart, I. Harrison, K. Irvine, S. C. Jähnig, J. M. Jeschke, J. J. Lee, C. Lu, A. M. Lewandowska, M. T. Monaghan, J. C. Nejstgaard, H. Patricio, A. Schmidt-Kloiber, S. N. Stuart, M. Thieme, K. Tockner, E. Turak \& O. Weyl, 2018. The Alliance for Freshwater Life: a global call to unite efforts for freshwater biodiversity science and conservation. Aquatic Conservation: Marine and Freshwater Ecosystems 28: 1015-1022.

de Graaf, M., H. J. Megens, J. Samallo \& F. A. Sibbing, 2007. Evolutionary origin of Lake Tana's (Ethiopia) small Barbus species: indications of rapid ecological divergence and speciation. Animal Biology 57: 39-48.

de Moor, F. C., 2011. A survey of Trichoptera from the Tributaries of the Doring and mainstream Olifants Rivers, Cedarberg, South Africa with implications for conservation. Zoosymposia 5: 350-359.

de Moor, F. C. \& J. A. Day, 2013. Aquatic biodiversity in the Mediterranean region of South Africa. Hydrobiologia 719: 237-268.

de Moor, F. C., H. M. Barber-James, A. D. Harrison \& C. R. Lugo-Ortiz, 2000. The macroinvertebrates of the Cunene River from the Ruacana Falls to the river mouth and assessment of the conservation status of the river. African Journal of Aquatic Science 25: 105-122.

Degefu, F., K. Teshome, G. Tesfaye, F. Tefera \& A. Lakew, 2011. Some limnological aspects of Koka Reservoir, a shallow tropical artificial lake, Ethiopia. Journal of Recent Trends in Biosciences 1: 94-100.

Degefu, F., A. Lakew, Y. Tigabu \& K. Teshome, 2013. The water quality degradation of upper Awash River, Ethiopia. Ethiopian Journal of Environmental Studies and Management 6: 58-66.

Dickens, C. W. S. \& P. M. Graham, 2002. The South African scoring system (SASS) version 5 rapid bioassessment method for rivers. African Journal of Aquatic Science 27: $1-10$.

Dufrêne, M. \& P. Legendre, 1997. Species assemblages and indicator species: the need for a flexible asymmetrical approach. Ecological Monographs 67: 345-366.

Edossa, D. C., M. S. Babel \& A. D. Gupta, 2010. Drought analysis in the Awash River Basin, Ethiopia. Water Resources Management 24: 1441-1460.

Englmaier, G. K., 2018. Longitudinal zonation of fish assemblages in a tropical river: Awash River Basin, central Ethiopia, With taxonomic and ecological considerations on the genus Garra (Teleostei: Cyprinidae). Master Thesis. University of Natural Resources and Life Sciences, Vienna.

Englmaier, G. K., G. Tesfaye \& N. G. Bogutskaya, 2020. A new species of Enteromius (Actinopterygii, Cyprinidae, Smiliogastrinae) from the Awash River, Ethiopia, and the reestablishment of E. akakianus. ZooKeys 902: 95-138.
Fazzini, M., C. Bisci \& P. Billi, 2015. Chapter 3: the climate of Ethiopia. In Billi, P. (ed.), Landscapes and Landforms of Ethiopia, World Geomorphological Landscapes. Springer, Dordrecht: 65-87.

Fitzgerald, D. B., M. H. Sabaj Perez, L. M. Sousa, A. P. Gonçalves, L. Rapp Py-Daniel, N. K. Lujan, J. Zuanon, K. O. Winemiller \& J. G. Lundberg, 2018. Diversity and community structure of rapids-dwelling fishes of the Xingu River: implications for conservation amid large-scale hydroelectric development. Biological Conservation 222: 104-112.

Foerster, V., A. Junginger, A. Asrat, H. F. Lamb, M. Weber, J. Rethemeyer, U. Frank, M. C. Brown, M. H. Trauth \& F. Schaebitz, 2014. 46000 Years of alternating wet and dry phases on decadal to orbital timescales in the cradle of modern humans: the Chew Bahir Project, southern Ethiopia. Climate of the Past Discussions 10: 977-1023.

Getahun, A., 2000. Systematic studies of the African species of the genus Garra (Pisces: Cyprinidae). Doctoral Thesis. City University of New York, New York.

Gibon, F. M. \& B. Statzner, 1985. Longitudinal zonation of lotic insects in the Bandama River system (Ivory Coast). Hydrobiologia 122: 61-64.

Goerner, A., E. Jolie \& R. Gloaguen, 2009. Non-climatic growth of the saline Lake Beseka, Main Ethiopian Rift. Journal of Arid Environments 73: 287-295.

Golubtsov, A. S. \& M. V. Mina, 2003. Fish species diversity in the main drainage systems of Ethiopia: current state of knowledge and research perspectives. Ethiopian Journal of Natural Resources 5: 281-318.

Golubtsov, A. S., Yu. Yu. Dgebuadze \& M. V. Mina, 2002. Chapter 10: fishes of the Ethiopian Rift Valley. In Tudorancea, C. \& W. D. Taylor (eds), Ethiopian Rift Valley Lakes. Biology of Inland Waters Series. Backhuys Publishers, Leiden: 167-258.

Grill, G., B. Lehner, M. Thieme, B. Geenen, D. Tickner, F. Antonelli, S. Babu, P. Borrelli, L. Cheng, H. Crochetiere, H. Ehalt Macedo, R. Filgueiras, M. Goichot, J. Higgins, Z. Hogan, B. Lip, M. E. McClain, J. Meng, M. Mulligan, C. Nilsson, J. D. Olden, J. J. Opperma, P. Petry, C. Reidy Liermann, L. Sáenz, S. Salinas-Rodríguez, P. Schelle, R. J. P. Schmitt, J. Snider, F. Tan, K. Tockner, P. H. Valdujo, A. van Soesbergen \& C. Zarfl, 2019. Mapping the world's free-flowing rivers. Nature 569: 215-236.

Grove, A. T., F. A. Street \& A. S. Goudie, 1975. Former lake levels and climatic change in the Rift Valley of southern Ethiopia. The Geographical Journal 141: 177-202.

Habteselassie, R., 2012. Fishes of Ethiopia, Annotated Checklist with Pictorial Identification Guide, 1st ed. Ethiopian Fisheries and Aquatic Science Association, Addis Ababa.

Habteselassie, R., E. Mikschi, H. Ahnelt \& H. Waidbacher, 2010. Garra chebera, a new species of cyprinid fish from an isolated basin in Ethiopia (Teleostei: Cyprinidae). Annalen des Naturhistorischen Museums in Wien 111: 43-53.

Harrison, A. D. \& J. F. Elsworth, 1958. Hydrobiological Studies on the Great Berg River, Western Cape Province. Transactions of the Royal Society of South Africa 35: 125-226.

Hawkes, H. A., 1975. River zonation and classification. In Whitton, B. A. (ed.), River Ecology. Blackwell Scientific Publications, Oxford: $312-374$. 
Hayes, D. S., J. M. Brändle, C. Seliger, B. Zeiringer, T. Ferreira \& S. Schmutz, 2018. Advancing towards functional environmental flows for temperate floodplain rivers. Science of the Total Environment 633: 1089-1104.

Hayes, D. S., P. Branco, J. M. Santos \& T. Ferreira, 2019. Oxygen depletion affects kinematics and shoaling cohesion of cyprinid fish. Water 11: 642 .

Huet, M., 1949. Apercu des relations entre la pente et les Populations piscicoles des eaux courantes. Schweizerische Zeitschrift für Hydrologie 11: 332-351.

Ibanez, C., T. Oberdorff, G. Teugels, V. Mamononekene, S. Lavouè, Y. Fermon, D. Paugy \& A. K. Toham, 2007. Fish assemblages structure and function along environmental gradients in rivers of Gabon (Africa). Ecology of Freshwater Fish 16: 315-334.

Illies, J., 1961a. Gebirgsbäche in Europa und in Südamerika ein limnologischer Vergleich. Verhandlungen des Internationalen Verein Limnologie 14: 517-523.

Illies, J., 1961b. Versuch einer allgemeinen biozönotischen Gliederung der Fließgewässer. Internationale Revue der gesamten Hydrobiologie 46: 205-213.

Illies, J. \& L. Botosaneanu, 1963. Problèmes et méthodes de la classification et de la zonation écologique des eaux courantes, considerées surtout du point de vue faunistique. Internationale Vereinigung für Theoretische und Angewandte Limnologie 12: 1-57.

Jones, J. I., J. F. Murphy, A. L. Collins, D. A. Sear, P. S. Naden \& P. D. Armitage, 2007. The impact of fine sediment on macro-invertebrates. River Research and Applications 28: 1055-1071.

Junk, W., P. B. Bayley \& R. E. Sparks, 1989. The flood pulse concept in river-floodplain systems. In Dodge, D. P. (ed.), Proceedings of the International Large River Symposium. Canadian Special Publication of Fisheries and Aquatic Sciences: 110-127.

Kaaya, L. T., J. Day \& H. F. Dallas, 2015. Tanzania River Scoring System (TARISS): a macroinvertebrate-based biotic index for rapid bioassessment of rivers. African Journal of Aquatic Science 40: 109-117.

Kebede, G., D. Mushi, R. B. Linke, O. Dereje, A. Lakew, D. S. Hayes, A. H. Farnleitner \& W. Graf, 2020. Macroinvertebrate indices versus microbial fecal pollution characteristics for water quality monitoring reveals contrasting results for an Ethiopian river. Ecological Indicators 108: 105733.

Keraga, A. S., Z. Kiflie \& A. N. Engida, 2019. Evaluation of SWAT performance in modeling nutrients of Awash River Basin, Ethiopia. Modeling Earth Systems and Environment 5: 275-289.

Kimmins, D. E., 1963. On the Trichoptera of Ethiopia. Bulletin of the British Museum (Natural History), Entomology 13: 119-170.

Kjærandsen, J. \& T. Andersen, 1997. Preliminary check-list of the caddisflies (Trichoptera) of Ghana, West-Africa. In Holzenthal, R. W. \& O. S. Flint Jr. (eds), Proceedings of the 8th International Symposium on Trichoptera, Ohio: 239-247.

Kropáček, J., C. Schillaci, R. Salvini \& M. Märker, 2016. Assessment of gully erosion in the Upper Awash, Central Ethiopian Highlands based on a comparison of archived aerial photographs and very high resolution satellite images. Geografia Fisica e Dinamica Quaternaria 39: 161-170.

Lakew, A. \& O. Moog, 2015. A multimetric index based on benthic macroinvertebrates for assessing the ecological status of streams and rivers in central and southeast highlands of Ethiopia. Hydrobiologia 751: 229-242.

Lamberti, G. A. \& V. H. Resh, 1985. Distribution of benthic algae and macroinvertebrates along a thermal stream gradient. Hydrobiologia 128: 13-21.

Laudee, P. \& T. O. Prommi, 2011. Biodiversity and distribution of Trichoptera species along the Tapee River, Surat Thani Province, southern Thailand. In Majecka, K., J. Majecki \& J. C. Morse (eds), Proceedings of the 13th International Symposium on Trichoptera. Zoosymposia: 279-287.

Le Turdu, C., J. J. Tiercelin, E. Gibert, Y. Travi, K. E. Lezzar, J. P. Richert, M. Massault, F. Gasse, R. Bonnefille, M. Decobert, B. Gensous, V. Jeudy, E. Tamrat, M. U. Mohammed, K. Martens, B. Atnafu, T. Chernet, D. Williamson \& M. Taieb, 1999. The Ziway-Shala Lake Basin System, Main Ethiopian Rift: influence of volcanism, tectonics, and climatic forcing on basin formation and sedimentation. Palaeogeography, Palaeoclimatology, Palaeoecology 150: 135-177.

Lévêque, C., C. Dejoux \& A. Iltis, 1983. Limnologie du fleuve Bandama, Côte d'Ivoire. Hydrobiologia 100: 113-141.

Levin, B. A., 2012. New data on morphology of the African scraping feeder Varicorhinus beso (Osteichthyes: Cyprinidae) with the special reference to specialized traits. Journal of Ichthyology 52: 908-923.

Lorenz, C. M., A. J. Gilbert \& W. P. Cofino, 2001. Indicators for transboundary river management. Environmental Management 28: 115-129.

Malicky, H., 1994. Eine reliktäre Köcherfliegenlarve von den Seychellen mit ungewöhnlicher Ernährungsweise (Hughscottiella auricapilla, Atriplectidae, Trichoptera). Natur und Museum 124: 233-238.

Malicky, H., 2005. Ein kommentiertes Verzeichnis der Köcherfliegen (Trichoptera) Europas und des Mediterrangebietes. Linzer biologische Beiträge 37: 533-596.

Malicky, H., 2014. Lebensräume von Köcherfliegen. Denisia 34: $1-280$.

Malicky, H., 2019. Phänologische Studien an tropischen Trichopteren: Bang Khun Klang (Thailand). Braueria 46: 27-35.

Malicky, H. \& P. Chantaramongkol, 1993. The altitudinal distribution of Trichoptera species in Mae Klang Catchment on Doi Inthanon, northern Thailand: stream zonation and cool- and warm-adapted groups. Revue d'Hydrobiologie Tropicale 26: 279-291.

Malicky, H. \& W. Graf, 2012. Eine kleine Trichopterenausbeute aus Äthiopien. Braueria 39: 32-38.

Malicky, H. \& W. Graf, 2015. Einige neue afrikanische Köcherfliegen (Trichoptera). Braueria 42: 31-35.

Marlier, G., 1954. Recherches hydrobiologiques dans les rivières du Congo Oriental. II. Étude écologique. Hydrobiologia 6: 225-264.

Masese, F. O., M. Muchiri \& P. O. Raburu, 2009. Macroinvertebrate assemblages as biological indicators of water quality in the Moiben River, Kenya. African Journal of Aquatic Science 34: 15-26. 
McCune, B. \& M. J. Mefford, 2006. PC-ORD. Multivariate Analysis of Ecological Data. Version 5. MjM Software Design, Gleneden Beach.

Meulenbroek, P., S. Stranzl, A. Oueda, J. Sendzimir, K. Mano, I. Kabore, R. Ouedraogo \& A. Melcher, 2019. Fish communities, habitat use, and human pressures in the Upper Volta Basin, Burkina Faso, West Africa. Sustainability 11: 5444.

Ministry of Environment, Forest and Climate Change (MEFCC), 2018. Towards a Water Management Programme for the Awash Basin.

Moog, O., A. Chovanec, J. Hinteregger \& A. Römer, 1999. Richtlinie zur Bestimmung der saprobiologischen Gewässergüte von Fließgewässern. Bundesministerium für Landund Forstwirtschaft, Wasserwirtschaftskataster, Wien.

Moritz, T., N. Straube \& D. Neumann, 2019. The Garra species (Cyprinidae) of the Main Nile Basin with description of three new species. Cybium 43: 311-329.

Morse, J. C. (ed), 2020. Trichoptera World Checklist. [available on internet at https://entweb.sites.clemson.edu/database/ trichopt/]. Accessed 15 Jan 2020.

Mosely, M. E., 1931. Some new Trichoptera from Africa and British Guiana. Transactions of the Entomological Society of London 79: 545-551.

Mosely, M. E., 1939. New African caddisflies (Trichoptera). Annals and Magazine of Natural History Series 3: 1-28.

Mosely, M. E., 1948. Trichoptera collected by Miss R.H. Lowe at Lake Nyasa. Annals and Magazine of Natural History Series 1: 31-47.

Nyssen, J., A. Frankl, A. Zenebe, J. Deckers \& J. Poesen, 2015. Land management in the Northern Ethiopian Highlands: local and global perspectives; past, present and future. Land Degradation and Development 26: 759-764.

Ochieng, H., J. Okot-Okumu \& R. Odong, 2019. Taxonomic challenges associated with identification guides of benthic macroinvertebrates for biomonitoring freshwater bodies in East Africa: a review. African Journal of Aquatic Science 44: 113-126.

Ogbogu, S. S., 2008. Description of mature larva of the genus Oecetis McLachlan (Trichoptera, Leptoceridae) from southwestern Nigeria, West Africa. Journal of Afrotropical Zoology 4: 71-76.

Ogbogu, S. S. \& E. E. Okeze, 2008. Description of the larva of Triaenodes sp. McLachlan, 1865 (Trichoptera: Leptoceridae) from Ile-Ife, Nigeria. Ife Journal of Science 10: 73-76.

Oksanen, J., F. G. Blanchet, R. Kindt, P. Legendre, P. R. Minchin, R. B. O’Hara, G. L. Simpson, P. Solymos, M. Henry, H. Stevens, E. Szoecs \& H. Wagner, 2015. Vegan: Community Ecology Package. R Package, Version 2.3-1 [available on internet at https://cran.r-project.org/web/]. Accessed 9 Sept 2019.

Olah, J. \& K. A. Johanson, 2008. Generic review of Hydropsychinae, with description of Schmidopsyche, new genus, 3 new genus clusters, 8 new species groups, 4 new species clades, 12 new species clusters and 62 new species from the Oriental and Afrotropical regions (Trichoptera: Hydropsychidae). Zootaxa 1802: 1-248.

Paugy, D., 2010. The Ethiopian subregion fish fauna: an original patchwork with various origins. Hydrobiologia 649: 301-315.
Payne, A. I., R. C. Wakeford \& T. E. Ndomahina, 2010. Fish distribution and zonation along a tropical African river, the Rokel/Seli River, Sierra Leone, West Africa. Smithiana Bulletin 12: 25-38.

Prokofiev, A. M. \& A. S. Golubtsov, 2013. Revision of the loach genus Afronemacheilus (Teleostei: Balitoridae: Nemacheilinae) with description of a new species from the Omo-Turkana Basin, Ethiopia. Ichthyological Exploration of Freshwaters 24: 1-14.

R Core Team, 2017. R: A Language and Environment for Statistical Computing [available on internet at https://www.rproject.org]. Accessed 9 Sep 2019.

Roberts, T. R., 1975. Geographical distribution of African freshwater fishes. Zoological Journal of the Linnean Society 57: 249-319.

Sabater, S., F. Bregoli, V. Acuña, D. Barceló, A. Elosegi, A. Ginebreda, R. Marcé, I. Muñoz, L. Sabater-Liesa \& V. Ferreira, 2018. Effects of human-driven water stress on river ecosystems: a meta-analysis. Scientific Reports 8: 11462.

Sagri, M., C. Bartolini, P. Billi, G. Ferrari, M. Benvenuti, S. Carnicelli \& F. Barbano, 2008. Latest Pleistocene and Holocene river network evolution in the Ethiopian Lakes Region. Geomorphology 94: 79-97.

Schmidt, R. C., 2014. Historical biogeography of fishes of the Fouta Djallon highlands and surrounding areas. Doctoral Thesis. Tulane University, New Orleans.

Schmidt-Kloiber, A. \& D. Hering, 2015. www.freshwaterecology.info - an online tool that unifies, standardises and codifies more than 20,000 European freshwater organisms and their ecological preferences. Ecological Indicators 53: 271-282.

Scott, K. M. F., 1975. The value of larval stages in systematic studies of the Trichoptera, with particular reference to the Hydropsychidae from Africa south of the Sahara. In Proceedings of the 1st Congress of the Entomological Society of South Africa: 41-52.

Scott, K. M. F., 1983. On the Hydropsychidae (Trichoptera) of Southern Africa with keys to African genera of imagos, larvae and pupae and species list. Annals of the Cape Provincial Museums Natural History 14: 299-422.

Scott, K. H. F., 1986. A brief conspectus of the Trichoptera (Caddisflies) of the Afrotropical Region. Journal of the Entomological Society of Southern Africa 49: 231-238.

Scott, K. H. F., 1993. Three recently erected Trichoptera families from South Africa, the Hydrosalpingidae, Petrothrincidae and Barbarochthonidae (Integripalpia: Serocostomatoidea). Annals of the Cape Provincial Museum, Natural History 18: 293-354.

Siege, L. \& C. Koch, 2017. Systematic status of crocodiles in the Awash River catchment. Crocodile Specialist Group Newsletter 36: 24-26.

Skelton, P. H., 2001. A Complete Guide to the Freshwater Fishes of Southern Africa. Struik Publishers, Cape Town.

Skelton, P. H. \& E. R. Swartz, 2011. Walking the tightrope: trends in African freshwater systematic ichthyology. Journal of Fish Biology 79: 1413-1435.

Stanford, J. A., F. R. Hauer \& J. V. Ward, 1988. Serial discontinuity in a large river system. Internationale Vereinigung für theoretische und angewandte Limnologie 23: 1114-1118. 
Statzner, B. \& B. Higler, 1985. Questions and comments on the river continuum concept. Canadian Journal of Fisheries and Aquatic Sciences 42: 1038-1044.

Statzner, B. \& B. Higler, 1986. Stream hydraulics as a major determinant of benthic invertebrate zonation patterns. Freshwater Biology 16: 127-139.

Stewart, K. M. \& K. M. Murray, 2017. Biogeographic implications of fossil fishes from the Awash River, Ethiopia. Journal of Vertebrate Paleontology 37: e1269115.

Stiassny, M. L. J. \& A. Getahun, 2007. An overview of labeonin relationships and the phylogenetic placement of the AfroAsian genus Garra Hamilton, 1922 (Teleostei: Cyprinidae), with the description of five new species of Garra from Ethiopia, and a key to all African species. Zoological Journal of the Linnean Society 150: 41-83.

Tadese, M. T., L. Kumar, R. Koech \& B. Zemadim, 2019. Hydro-climatic variability: a characterisation and trend study of the Awash River Basin, Ethiopia. Hydrology 6: 35.

Tafere, M., J. Olivier \& M. Jordaan, 2013. Major human and natural disruptions that facilitated vegetation cover removal in the Ethiopian Highlands. Journal of Environment and Earth Science 3: 143-151.

Terefe, Y., S. Vitecek \& W. Graf, 2018. Description of the larva of Oecetis mizrain Malicky \& Graf, 2012 (Trichoptera, Leptoceridae) and Lepidostoma scotti (Ulmer, 1930) (Trichoptera, Lepidostomatidae) from Chilimo Forest, Central Ethiopia. ZooKeys 766: 63-77.

Tesfaye, G. \& M. Wolff, 2014. The state of inland fisheries in Ethiopia: a synopsis with updated estimates of potential yield. Ecohydrology and Hydrobiology 14: 200-219.

Thienemann, A., 1925. Die Binnengewässer Mitteleuropas: Eine Limnologische Einführung, Vol. I. E. Schweizerbartsche Verlagsbuchhandlung, Stuttgart.

Thorp, J. H., M. C. Thoms \& M. D. Delong, 2006. The riverine ecosystem synthesis: biocomplexity in river networks across space and time. River Research and Applications 22: 123-147.

Tobias, D. \& W. Tobias, 2008. Trichoptera africana [available on internet at http://www.trichoptera.insects-online.de/
Trichoptera\%20africana/index.htm]. Accessed 15 Oct 2019.

Uherkovich, Á. \& S. Nógrádi, 2018. A tegzesek (Trichoptera) kutatásának eredményei a Dráva hazai vízgyüjtőjén az elmúlt negyven évben. Natura Somogyiensis 32: 37-92.

Vannote, R. L., G. W. Minshall, K. W. Cummins, J. R. Sedell \& C. E. Cushing, 1980. The river continuum concept. Canadian Journal of Fisheries and Aquatic Sciences 37: 130-137.

Ward, J. V., C. T. Robinson \& K. Tockner, 2002. Applicability of ecological theory to riverine ecosystems. Verhandlungen der Internationale Vereinigung für Theoretische und Angewandte Limnologie 28: 443-450.

Ward, J. V. \& J. A. Stanford, 1983. The serial discontinuity concept of lotic ecosystems. In Fontaine, T. D. \& S. M. Bartell (eds), Dynamics of Lotic Ecosystems. Science Publishers, Ann Arbor: 29-42.

Ward, J. V. \& J. A. Stanford, 1995. The serial discontinuity concept: extending the model to floodplain rivers. Regulated Rivers: Research and Management 10: 159-168.

Welcome, R. L., K. O. Winemiller \& I. G. Cowx, 2005. Fish environmental guilds as a tool for assessment of ecological condition of rivers. River Research and Applications 21: $1-20$.

Winemiller, K. O., 2004. Floodplain river food webs: generalizations and implications for fisheries management. In Welcomme, R. \& T. Petr (eds), Proceedings of the Second International Symposium on the Management of Large Rivers for Fisheries, Vol. II. Regional Office for Asia and the Pacific, Bangkok: 285-309.

Winemiller, K. O., A. A. Agostinho \& E. P. Caramaschi, 2008. Chapter 5: fish ecology in tropical streams. In Dudgeon, D. (ed.), Tropical Stream Ecology. Academic, San Diego: 107-149.

Publisher's Note Springer Nature remains neutral with regard to jurisdictional claims in published maps and institutional affiliations. 